\title{
Host Genetics and Pediatric Sepsis
}

\author{
Anil Sapru ${ }^{1}$ and Michael W. Quasney*,2 \\ ${ }^{I}$ Department of Pediatrics, University of California, San Francisco, CA, and the ${ }^{2}$ Division of Critical Care, Department \\ of Pediatrics, Medical College of Wisconsin and the Children's Research Institute, Milwaukee, WI, USA
}

\begin{abstract}
Susceptibility to, and outcome from, sepsis in children is highly variable due in part to genetic variation in genes coding for components of the innate immune response. This review article will discuss evidence for the influence of host genetic variability on the susceptibility to, and outcome from, sepsis in children and adults. Polymorphisms in genes coding for proteins involved in the recognition of bacterial pathogens (TLR4, CD-14, Fc $\gamma$ RIIa, and mannose binding lectin) and the response to bacterial pathogens (TNF- $\alpha$, IL- $1 \alpha$, IL-1 $\beta$, IL- $1_{\mathrm{RA}}$, IL-6, IL-10, heat shock proteins, ACE, plasminogen activator inhibitor-1) can influence the amount or function of the protein produced in response to bacterial stimuli. Evidence is discussed suggesting that some of these genetic polymorphisms influence the susceptibility to, and outcome from, sepsis.

Conclusion: Host genetic variability in the regulatory and coding regions of genes for components of the innate immune system may influence the susceptibility to and/or outcome from sepsis. The disparate results observed in many studies of polymorphisms in sepsis emphasize the need for future studies to be larger, to include the analysis of multiple polymorphisms, and to be better designed with respect to control populations in order to identify the degree of influence that genetic variability has on sepsis.
\end{abstract}

Keywords: Sepsis, polymorphism, pediatrics, outcome, genetics.

\section{INTRODUCTION}

Sepsis remains a major global health problem with a high mortality despite major advances in the care of critically ill children and adults. Examining why certain patients continue to have a high mortality may provide clues to novel therapeutic interventions. Recent research has explored the hypothesis that common genetic variations within each of us may either contribute to or influence the severity of infections, thereby contributing to the high mortality in sepsis.

The sequencing of the human genome has revealed the enormous degree of genetic variation that exists in the human population. Indeed, most genes are polymorphic meaning that they exhibit small differences in their nucleotide sequence. These variations account for the hereditable differences among us all, including how we respond to illnesses. Recent studies have suggested that clinical presentation, treatment, and outcome from critical illnesses are influenced in part by some of these genetic variations. These genetic variations may contribute to why one child with viral or bacterial pneumonia presents to the emergency department and is well enough to go home, while another child with the same pathogen presents in fulminate septic shock and respiratory failure. Thus, host genetic variations may influence the response to infection and

*Address correspondence to this author at the Division of Critical Care, Department of Pediatrics, Medical College of Wisconsin, and the Children's Research Institute, Milwaukee, WI, 9000 W. Wisconsin Ave, MS681, Milwaukee, WI 53201, USA; Tel: (414) 266-3360;

Fax: (414) 266-3563; E-mail: mquasney@mcw.edu severity of disease [1-3]. That host genetics may play a role in the outcomes from sepsis is supported by the observation that an early death of a biologic parent from infection is associated with a much greater risk of death of a child from infection than the death of an adoptive parent from infection on the risk of death of an adopted child from infection [4]. An understanding of the host factors which contribute to the susceptibility to, and outcome from, sepsis is crucial given the major impact of sepsis on the morbidity and mortality in neonatal, pediatric, and adult intensive care units.

The innate immune response enables the host to recognize pathogens and provide a rapid inflammatory response that includes the production of cytokines, chemokines, and effector molecules and allows for the interaction with the adaptive immune response [5]. This innate immune system, therefore, must first differentiate self from pathogen by identifying the presence of pathogenassociated products and, second, respond by activating a number of signaling pathways whose end result is the synthesis of inflammatory cytokines and counterbalanced by the production of anti-inflammatory cytokines. Indeed, severe sepsis is thought to be perpetuated by the exaggerated systemic production of inflammatory cytokines not adequately counterbalanced by the production of antiinflammatory cytokines [6-9]. These two components of the innate immune system, recognition and response, utilize a large number of receptors and accessory proteins, signaling molecules, and transcription factors involved in protein synthesis. Any part of the recognition and response components that is altered in quantity or functional activity may ultimately influence the final host response. Thus, the number of possible genes in which variations might 
influence the innate immune response, and thereby the susceptibility to, and outcome from, sepsis is considerably large. This review will examine the evidence of the influence of host genetic variability in patients with sepsis and Table $\mathbf{1}$ summarizes many of the studies.

\section{GENETIC VARIATION IN PATHOGEN RECOGNI- TION MOLECULES}

The host response to infection requires recognition of the presence of pathogen-associated compounds, also termed pathogen-associated molecular patterns (PAMPs), and the subsequent initiation of a number of signaling pathways. The following section reviews the evidence that genetic polymorphisms in genes coding for recognition of PAMPs influence the susceptibility to and outcome from sepsis.

\section{Toll-Like Receptors}

The demonstration that the Drosophila protein Toll was crucial for the protection of the fly against fungal infections [10] greatly enhanced our understanding of the innate immune system at the molecular level. The human toll-like receptors (TLR) are a family of cell surface and intracellular receptors that are involved in pathogen recognition [11-14]. These receptors recognize a variety of diverse bacterial, viral, and fungal pathogens and allow for the induction of the appropriate signaling pathways in order initiate a pathogen specific response.

Perhaps the best studied of the TLRs is TLR4 which along with the accessory proteins CD-14 and MD-2, binds LPS, one of the major components of the cell wall of gram negative bacteria and a powerful stimulator of the innate immune response. Several studies in mice demonstrate that TLR4 is required for response to LPS [15] and that a single amino acid change can significantly reduce response to LPS $[16,17]$ and enhance susceptibility to infection. Several SNPs have been identified in the promoter and coding regions of the human TLR4 gene [18-20]. The SNP identified in the fourth exon of the TLR4 gene results in the replacement of a conserved aspartic acid at amino acid residue 299 with glycine. This SNP is in linkage disequilibrium with a second SNP at amino acid 399 which changes a threonine to an isoleucine. The Gly299Ile399 variant appears to be expressed at lower levels in human airway epithelia [18], and a number of studies have demonstrated an association of this variant with a reduced airway reactivity in response to inhaled LPS [18, 19, 21]. This variant is associated with a decreased response to LPS in in vitro studies utilizing primary human epithelial cells heterozygous for the variant as well as in studies using a transfected cell system [18].

Do individuals with the TLR4 genetic variants associated with a decreased responsiveness to LPS have a greater likelihood of gram negative bacterial infection and/or sepsis? Human studies have demonstrated an association of these variants with susceptibility to gram negative bacterial infections and septic shock [22-24] and mortality in patients with systemic inflammatory response syndrome [25]. In addition, a TLR4 polymorphism was found to be associated with an increased risk of severe sepsis in adult burn patients [26]. However, not all studies have confirmed this finding $[27,28]$, nor does the variant appear to be associated with either susceptibility to, or severity of, meningococcal disease specifically [29]. This apparent lack of an association of the variant with meningococcal disease is complicated by findings demonstrating that Neisseria meningitides is capable of eliciting an inflammatory response via TLR2 in the absence of LPS thereby bypassing any genetic variation in the TLR4 gene that may influence the host's response [30, 31]. Thus, there is good evidence for the biologic plausibility that genetic variations in the TLR4 gene may influence the response to infections, but further studies are needed to assess whether these genetic variations influence the severity of sepsis in humans.

The TLR2 receptor recognizes a variety of PAMPs from gram positive and gram negative bacteria as well as fungus. Several genetic variations have been described in the promoter region and in the coding sequence of the gene for TLR2. One particular variation results in an arginine to glutamine at amino acid position 753 (arg753gln) that does not appear to increase the susceptibility to Staphylococcal aureus infections in humans [32]. In contrast, another study suggests that a promoter SNP in the TLR2 gene is associated with an increased prevalence of gram positive bacteremia and sepsis but not mortality [33] yet the mechanism by which this variation alters TLR2 levels or function is not known.

\section{Variations in Components of the TLR Complex and Signal Transduction Pathways}

The TLR signaling pathways are complex, and many details of the pathways remain to be determined. Fig. (1) demonstrates a simplified version of the TLR4 signaling pathway (for reviews see [34-36] and should help understand the notion that genetic variability in not only the TLRs themselves, but also their accessory proteins and signaling pathway components may also influence the susceptibility to, and outcome from, infection. The TLR4 receptor complex consists of two accessory proteins, CD14 and MD2. LPS fails to elicit a response in both CD14 [37] and MD-2 [38] knockout mice demonstrating their crucial role in the recognition of gram negative pathogens. A polymorphic site in the promoter region of the gene coding for CD-14 in humans has been identified 159 nucleotides upstream of the transcription start site ( $\mathrm{C}$ to $\mathrm{T})$ [39-41] with the $\mathrm{T}$ allele demonstrating increased transcriptional activity [42]. Individuals homozygous for the $-159 \mathrm{~T}$ allele have increased levels of CD14 [41-43]. While some human studies demonstrate an increased risk of sepsis or septic shock [33, 44], others have not demonstrated an association with outcome in adults with confirmed gram negative bacteremia [28] or sepsis $[45,46]$. The disparity in results may be due to inherent differences between the studies, such as the number of patients analyzed, origin of the infection (surgery, trauma, pneumonia), or heterogeneity of the patient populations.

Several genetic variations in the gene coding for MD-2 have been identified. One such variation alters a threonine at position 35 to an alanine and is associated with reduced TNF- $\alpha$ secretion in response to LPS in an in vitro stimulation assay [47]. Additional SNPs in the promoter region of the MD-2 gene have been identified $(-1625 \mathrm{C} / \mathrm{G}$, $1064 \mathrm{~A} / \mathrm{G}$, and $-475 \mathrm{~A} / \mathrm{T}$ ) with the $-1625 \mathrm{SNP}$ appearing to increase MD-2 expression [48]. In a cohort of adult Chinese 


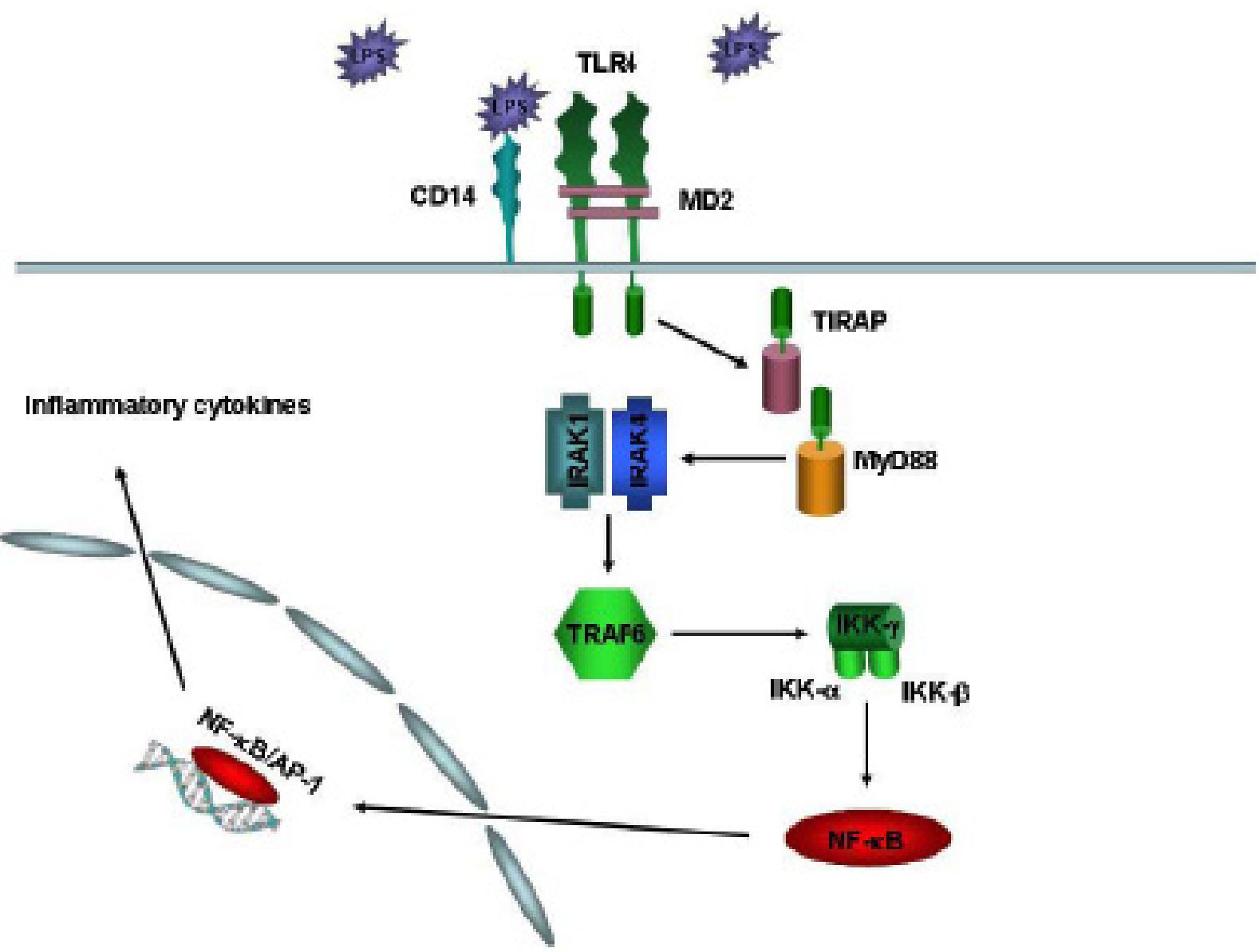

Fig. (1). A simplified schematic representation of the TLR4 signaling pathway. Genetic variations within any of the components of this pathway may influence the degree of the response to LPS. LPS, lipopolysaccharide; TLR4, toll-like receptor 4.

with trauma, those with the $-1625 \mathrm{G}$ allele were more likely to develop sepsis and organ dysfunction yet no affect on mortality is mentioned [48].

The TLR signaling pathways also include a number of adapter molecules (e.g., TIRAP/Mal, MyD88, and TRIF/TICAM-1) and intracellular kinases (e.g., IRAK-1, IRAK-4, and IKB) that transmit the signal to the nucleus. Some of these adapter molecules and kinases have functionally significant genetic variations that alter the signaling of the pathway and, thereby, the response. A polymorphism in the gene coding for TIRAP/Mal results in a ser180leu amino acid change and impaired TLR2 signaling. This variation is associated with a decreased risk of severe pneumococcal infection in those patients who are heterozygous for the polymorphism [49]. IRAK-1 is an intracellular kinase involved in TLR signaling. A specific haplotype containing a $\mathrm{T}$ to $\mathrm{C}$ polymorphism at nucleotide position +1595 within exon 12 is associated with increased nuclear translocation of $\mathrm{NF}-\mathrm{\kappa B}$ and increased risk for pneumococcal sepsis and higher mortality [50]. In addition, two polymorphisms in NF-IкB are associated with protection against invasive pneumococcal disease in adults [51]. Thus, genetic variations within the genes coding for the TLR receptors and components of their signal transduction pathways influence the final host response to infections and may account for some of the variation observed in sepsis.

\section{Mannose Binding Lectin}

Mannose binding lectin (MBL) is a circulating lectin that recognizes polysaccharide moieties of various pathogens [52-54]. MBL is involved with 1) the opsonization of bacteria by virtue of its ability to bind bacterial surface oligosaccharides [55], and, 2) the binding of MBLassociated serine proteases leading to activation of complement [56]. The MBL protein exists as a heterotrimer with each peptide containing a carbohydrate domain involved in pathogen recognition and a helical tail domain involved in polymerization of the 3 peptides [57]. Several lines of evidence support the critical role of MBL in innate immunity including an increased mortality with Staphylococcus aureus infections [58] and increased postburn infections with Psendomonas aeruginosa [59] in MBL-knockout mice.

Three genetic polymorphisms in the gene coding for human MBL result in changes in amino acids at positions 52, 54 and 57, (referred to as variants D, C, and B, respectively). These amino acid changes diminish the ability of the helical tails to polymerize resulting in an increased degradation of MBL [52, 60, 61] and reduced serum levels [60,62]. Two additional polymorphisms at nucleotides -550 and -221 in the promoter region appear to be associated with lower serum levels of MBL such that the final circulating levels of 

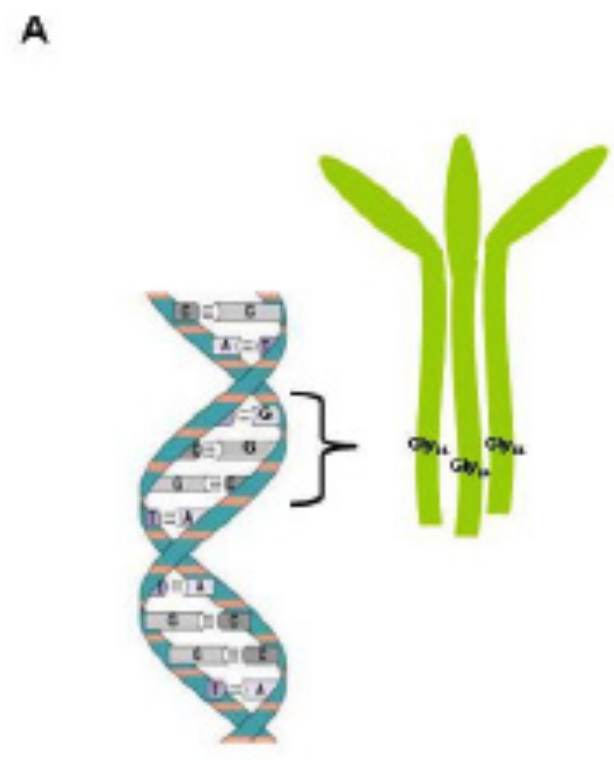

B

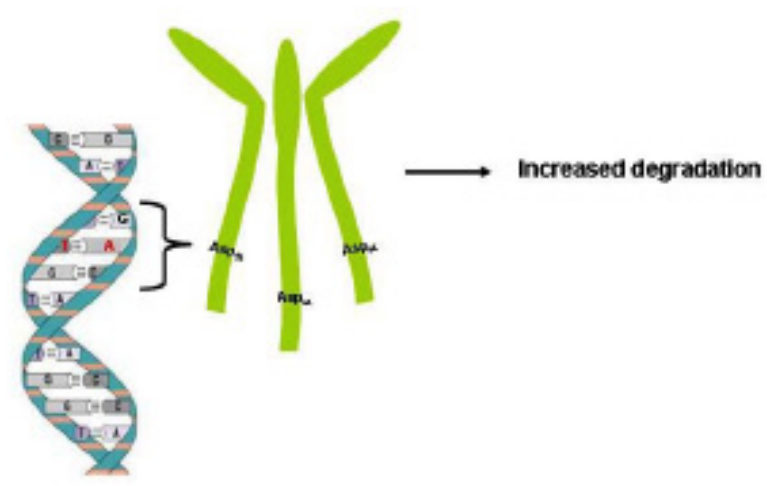

Fig. (2). Impact of the codon 54 genetic variation in the MBL2 gene on serum levels of MBL. The genetic variation in the gene coding for mannose binding lectin changes a guanine (Figure 2A) to an adenine (Figure $\mathbf{2 B}$ ) resulting in a glycine to aspartic acid change at amino acid position 54 in the helical tail of the MBL peptide. This amino acid change disrupts the conformation of the tail resulting in increased degradation of MBL and lower serum levels.

MBL are a reflection of the coding and promoter polymorphisms [63] (Fig. 2).

The 3 MBL structural variants $\mathrm{D}, \mathrm{C}$, and $\mathrm{B}$ are associated with an increased risk for meningococcal infections [64, 65], pneumonia and sepsis in neonates [66], acute respiratory infections in children [67], hospitalizations due to infections in children [68], recurrent respiratory infections [69], and viral co-infections in adults with pneumococcal pneumonia [70]. Three studies have examined MBL polymorphisms in patients with invasive pneumococcal disease [71-73], with one of these three studies finding a significant association. However, a recent meta-analysis of these three studies demonstrated a significant association between homozygosity and presence of disease [74]. The frequency of each of the 3 variants in patients who were homozygotes $(\mathrm{DD}, \mathrm{BB}$,
$\mathrm{CC})$ or heterozygotes $(\mathrm{BC}, \mathrm{BD}, \mathrm{CD})$ was significantly higher in patients than in a healthy control population suggesting an increased susceptibility to invasive pneumococcal disease in individuals with at least one copy of the variant polymorphism.

\section{GENETIC VARIATION IN GENES INVOLVED IN THE HOST RESPONSE TO PATHOGENS}

The host response to pathogens involves a number of cytokines and chemokines that coordinate and balance the overall response. Disruption of the various components can lead to an overwhelming inflammatory response that is detrimental to the host. Indeed, it is believed that an imbalance between the pro- and anti-inflammatory cytokines in favor of an overzealous response leads to the clinical picture of severe sepsis. Pro-inflammatory cytokines, notably TNF- $\alpha$, IL-1 and IL-6, are usually elevated early after an infection followed by an elevation of other mediators, such as chemokines. Anti-inflammatory cytokines such as IL-10 generally follow and lead to a return to baseline of cytokine and chemokine levels and the start of tissue repair [75-77]. Genetic variability within the genes coding for these components of the response could potentially disrupt this delicate balance and influence the severity of and outcome from sepsis.

\section{Tumor Necrosis Factor $\alpha$ (TNF- $\alpha)$}

As a pro-inflammatory cytokine, TNF- $\alpha$ plays a key role in the pathogenesis of the acute inflammatory response. TNF- $\alpha$ also appears to play a central role in development of the harmful effects of the inflammatory response such as hypotension, capillary leak, ARDS, and multi-organ failure [78-82]. An over-exaggerated pro-inflammatory response resulting in an imbalance between the pro-inflammatory cytokines such as TNF- $\alpha$ and the anti-inflammatory cytokines results in the clinical manifestation of sepsis and septic shock. One of the mechanisms by which an imbalance can occur is the presence of genetic variations that lead to increased levels of the pro-inflammatory cytokines or decrease levels of the anti-inflammatory cytokines.

Several single nucleotide polymorphisms within the regulatory region of the gene coding for TNF- $\alpha$ have been identified that are associated with both basal and stimulated TNF- $\alpha$ production in vitro and/or in vivo [83-90]. A well studied SNP is the G to A transition at nucleotide position 308 upstream from the transcriptional start site. In vitro studies have demonstrated that the rarer TNF- $\alpha-308 \mathrm{~A}$ allele is associated with increased transcription as compared with the wild-type TNF- $\alpha-308 \mathrm{G}$ allele [89]. Furthermore, the TNF- $\alpha-308 \mathrm{~A}$ allele is associated with increased secretion of TNF- $\alpha$ from macrophages after LPS stimulation in vitro [86]. This polymorphism lies near putative DNA binding sites for several transcription factors. Eletrophoretic mobility shift assays (EMSA) have demonstrated differential binding of nuclear proteins to DNA fragments containing either an A or a $\mathrm{G}$ at the TNF- $\alpha-308$ position [91]. A second polymorphism at position -238 lies in a putative repressor binding site in the promoter region [92]. The less common A allele that substitutes for the more common $G$ allele is associated with lower levels of transcription and secretion of TNF- $\alpha$ in in vitro studies [93]. A third polymorphism that appears to influence levels of TNF- $\alpha$ is approximately 250 
bp downstream from the transcriptional start site for the gene coding for lymphotoxin alpha (LT- $\alpha$, also known as TNF- $\beta$ ). This site is approximately 3.2 kilobases upstream from the TNF- $\alpha$ gene and may be acting as an enhancer region, though the exact mechanisms by which this polymorphism results in higher TNF- $\alpha$ levels are unknown. An A at this position is associated with higher TNF- $\alpha$ production in vitro as well as higher serum levels in adults with sepsis and children with bacteremia $[83,84,90]$. Thus, there is convincing evidence that genetic variation within regulatory regions of the gene coding for TNF- $\alpha$ influences TNF- $\alpha$ production.

Associations between TNF- $\alpha$ regulatory polymorphisms that result in higher TNF- $\alpha$ levels and the severity of, and outcome from, sepsis are observed in several studies. For example, among adults with septic shock, the frequency of the less common A allele at the TNF- $\alpha-308$ position is higher in those who died, and the risk of death was 3.7-fold greater in those patients with at least one copy of the TNF- $\alpha-$ 308A allele even after controlling for age and severity of illness [94]. Other studies demonstrating an association of "high-secretor" genotypes and more severe disease include children with meningococcal infections [95] and bacteremia [90], severe sepsis in adults [26, 83, 85, 96], and community acquired pneumonia in adults [97, 98]. However, these results have not been uniformly observed [28, 99-103], and further studies are needed. Thus, individuals in which genetic variations result in a hyper-response during sepsis (as with those with the TNF- $\alpha-308 \mathrm{~A}$ allele) or hypo-response (as with those with the TNF- $\alpha-238 \mathrm{~A}$ allele) may have worse outcomes with sepsis.

\section{Interleukin 1 and Interleukin 1 Receptor Antagonist (IL-1/IL-1 RA $_{\text {) }}$}

IL-1 $\alpha$ and IL-1 $\beta$ are also key pro-inflammatory cytokines secreted early in the response to infection and play an important role in the pathogenesis of sepsis and septic shock. These molecules stimulate the production of prostaglandins and nitric oxide, two mediators of the vasodilatation observed in sepsis [104]. IL- $1_{\mathrm{RA}}$ is produced to balance the specific effects of IL- $1 \beta$ by competing with IL-1 for binding to its receptor $[105,106]$. Serum levels of IL-1 $\beta$ and IL- $1_{\text {RA }}$ are elevated in patients with meningococcal disease with the highest levels in those with more severe disease [107].

The genes coding for IL- $1 \alpha$, IL- $1 \beta$, and IL- $1_{\mathrm{RA}}$ are clustered together on chromosome 2 , and several polymorphisms have been described in this locus. Three types of polymorphisms have been described in the gene coding for IL-1 $\alpha$; a variable number of a $46 \mathrm{bp}$ repeats in intron 6 with unknown functional significance [108]; a $\mathrm{C}$ to $\mathrm{T}$ transition at position -889 in the regulatory region that appears to increase transcriptional activity of the IL- $1 \alpha$ gene [109] and increase levels of IL-1 $\alpha$ protein [110]; and several polymorphisms in the 3'untranslated region (UTR) some of which have been shown to be associated with higher IL-1 $\alpha$ levels in response to LPS in an in vitro system [111]. Several polymorphisms in the IL- $1 \beta$ gene are located both in the promoter and coding region with several associated with higher levels of IL-1 $\beta$ in in vitro stimulation assays [112114]. Polymorphisms have also been identified in the gene coding for IL- $1_{\mathrm{RA}}$. One such polymorphism consists of a SNP within exon 2 at nucleotide position +2018 [115] while a well studied variation consists of a variable number of tandem repeats (VNTR) in intron 2 that is associated with variability in circulating levels of IL- $1_{\mathrm{RA}}$ and IL-1 $\beta$ [116119]. In regards to the VNTR variation, most healthy individuals have either 4 copies (54\%) (referred to as the A4 allele) or 2 copies (34\%) (referred to as the A2 allele) of the 86 bp repeat [120]. The A2 allele is associated with higher serum levels of IL- $1_{\mathrm{RA}}$ and lower levels of IL-1 $\alpha$. In addition, mononuclear cells isolated from individuals with the A2 allele produce more IL- $1_{\mathrm{RA}}$ in vitro $[116,117]$.

Several of the IL-1 polymorphisms have been examined for association with susceptibility to, and outcome from, sepsis. The IL- $1_{\text {RA }}$ VNTR polymorphism is associated with a number of diseases in which inflammation plays a key role [121-125]. A higher frequency of the IL- $1_{\mathrm{RA}}$ A2 allele was demonstrated in Caucasian adults with severe sepsis compared with the frequency in a healthy Caucasian population [120], but there was no association with higher mortality within the population with sepsis. Similarly, a higher frequency of the IL- $1_{\mathrm{RA}} \mathrm{A} 2$ allele in a cohort of Chinese adults with sepsis was observed [126] as well as a higher mortality in adults with severe sepsis [122]. In contrast, a higher frequency of the A2 allele was not observed in a cohort of children with meningococcal disease compared with a healthy control population [127]. In a large cohort of predominantly pediatric patients with meningococcal disease, those with the IL- $1_{\mathrm{RA}}+2018$ polymorphism had a higher mortality [128], however, this polymorphism is in linkage disequilibrium with the IL- $1_{\mathrm{RA}}$ gene A2 allele and, thus, may be a marker for the A2 allele which appears to be associated with poor outcome, as described above. Finally, our group has found an association between the presence of the A2 allele and more severe lung disease in a large cohort of children with communityacquired pneumonia [125]. Thus, despite some conflicting findings, genetic variability in the IL-1 locus, particularly the IL- $1_{\mathrm{RA}}$ A2 allele, appears to place patients at greater risk for the development of sepsis and perhaps at greater risk for mortality.

\section{Interleukin 6 (IL-6)}

IL-6 is another pro-inflammatory cytokine induced by TNF- $\alpha$ that stimulates both B- and T-lymphocytes and is involved in the induction of fever and the hepatic acute phase protein synthesis. Along with TNF- $\alpha$ and IL-1, it is believed to be a key mediator in the response to stress and pathophysiology of multi-organ failure. High serum levels of IL-6 have been correlated with severe sepsis and worse outcome from sepsis [129-137].

The gene coding for IL-6 has several genetic variations in the promoter region [138] and coding sequences. A common polymorphism located at position -174 in the promoter region is a $\mathrm{G}$ to $\mathrm{C}$ substitution, and in vitro studies demonstrate an association of the $\mathrm{G}$ allele with increased expression of IL-6 [139]. In addition, serum levels of IL-6 are lower in adults with sepsis with the $C$ allele [140] and in healthy adults, the $\mathrm{G}$ allele is associated with higher basal serum levels of IL-6 [139]. In contrast, monocytes isolated from neonates with the $\mathrm{C}$ allele and stimulated with LPS 
produce more IL-6 than monocytes isolated from neonates with the $\mathrm{G}$ allele [141], the opposite of what is observed in adults. In this age group, the $\mathrm{C}$ allele also appears to be associated with a greater rise in IL-6 levels during an acute inflammatory response. Such differences may by explained by changes in the immune response which occur during development.

Genetic association studies have demonstrated mixed results in regards to the influence of IL-6 polymorphisms in patients with sepsis. In adult surgical patients with sepsis, no association between the genotypes and serum levels of IL-6 is demonstrated, nor are there significant differences in genotype distribution between critically ill patients and healthy controls, or between patients with or without sepsis [131]. A significantly lower frequency of the $-174 \mathrm{GG}$ genotype is associated with higher mortality in septic patients compared with surviving septic patients, suggesting that the GG genotype is in some fashion protective, or conversely carriage the $\mathrm{C}$ allele places individuals at risk. Indeed, in cohort of adult septic patients, the CC genotype was more frequent in those with shock [140]. Other SNPs also exist in the gene coding for IL-6 allowing for the analysis of haplotypes or combinations of various SNPs. One such group of haplotypes consists of polymorphisms at the $174(\mathrm{G} / \mathrm{C}),+1753(\mathrm{C} / \mathrm{G})$, and +2954 (G/C) nucleotide positions. In a cohort of critically ill adult patients with SIRS, while no association between each of the SNPs individually and worse clinical outcomes is observed, individuals with the $\mathrm{C} / \mathrm{C} / \mathrm{G}, \mathrm{G} / \mathrm{G} / \mathrm{G}$ or $\mathrm{G} / \mathrm{C} / \mathrm{C}$ haplotype demonstrate a higher mortality and more organ dysfunction [142]. In addition to suggesting that genetic variations within the IL-6 gene influence the severity of sepsis, these observations support the concept that in some instances haplotype analysis may be more valuable in identifying genetic associations compared with individual SNP analysis.

Studies in premature infants on the influence of the IL-6 polymorphisms in patients with sepsis find quite results. The $-174 \mathrm{G}$ allele associated with low levels of IL-6 appears to be associated with sepsis in Caucasian premature neonates $[143,144]$ while in an African-American cohort, it is the C allele that demonstrates this association [145]. Furthermore, a recent meta-analysis suggests that the IL-6 -174 polymorphism is not strongly associated with the risk of sepsis in this age group [146].

\section{Interleukin-10 (IL-10)}

The anti-inflammatory cytokines provide a counterbalance to the pro-inflammatory cytokines, dampening the inflammatory response and helping to protect the host from the detrimental effects of the inflammatory mediators. In addition to the anti-inflammatory cytokine IL- $1_{\mathrm{RA}}$ discussed previously, they include IL-10 and transforming growth factor (TGF) $[9,147,148]$. IL-10 is produced primarily by monocytes and down regulates the expression of a wide range of cytokines [149, 150]. Neutralization of IL-10 results in an exaggerated pro-inflammatory response and death in animal models, while administration of IL-10 confers protection $[9,151,152]$. However, over-expression of IL-10 may induce immunosuppression in bacterial sepsis and increase mortality by inhibiting bacterial clearance [153, $154]$.
IL-10 production appears to be regulated primarily at the transcriptional level. Three SNPs located in the promoter region upstream from the transcriptional start site, at positions $-1082(\mathrm{G} / \mathrm{A}),-819(\mathrm{C} / \mathrm{T})$, and $-592(\mathrm{C} / \mathrm{A})$, have been shown to affect IL-10 expression [155-157]. The $1082 \mathrm{G} / \mathrm{A}$ substitution occurs within a putative Ets transcription factor binding site, the $-819 \mathrm{C} / \mathrm{T}$ lies within a putative positive regulatory region, and the $-592 \mathrm{C} / \mathrm{A}$ polymorphism lies within a putative STA 3 binding site and a negative regulatory region $[156,158]$. There is significant linkage disequilibrium between the alleles at the -819 and 592 sites. Therefore, only 4 possible haplotypes of these 3 polymorphisms can occur (-1082/-819/-592): GCC, ACC, GTA, and ATA. The GCC/GCC haplotype is associated with higher IL-10 production in stimulated peripheral blood mononuclear cells [157]. Likewise, in studies in which only single SNPs were examined, stimulated whole blood from individuals with the $\mathrm{G}$ allele at the IL-10-1082 site [159] or the $\mathrm{C}$ allele at the IL-10-592 site [160] resulted in higher amounts of IL-10 compared with whole blood from individuals lacking these alleles. In addition, when the promoter regions from individuals homozygous for the 3 haplotypes GCC, ACC, and ATA were cloned into a luciferase vector and transiently transfected into cells, the GCC construct demonstrated significantly increased transcriptional activity compared to the ATA construct, while the ACC construct demonstrating an intermediate transcriptional activity [161]. Thus, in vitro evidence demonstrates that genetic variation in the promoter region of the gene coding for IL-10 influences the amount of IL-10 produced.

Excess levels of IL-10 may play a role in immunosuppression in bacterial sepsis [153], and high levels are associated with higher mortality in pneumococcal pneumonia [154] and more severe disease in adults with community-acquired pneumonia [162]. Given the associations between the IL-10 promoter haplotypes and higher IL-10 secretion, and high IL-10 levels and more severe disease, it follows that the IL-10 "high-secretor" haplotypes would be associated with more severe disease. However, genetic association studies have yielded conflicting results. The "high secretor" G allele at position 1082 was associated with more severe disease when compared with the "low secretor" A allele in a cohort of adults with community-acquired pneumonia [163]. In a cohort of patients with culture proven pneumococcal disease, $54 \%$ of those patients who developed septic shock had the "high secretor" G allele while only $16 \%$ of those patients who did not develop septic shock had this allele [159]. At the IL-10-592 site, there was no increased risk of sepsis in a cohort of critically ill adults with the "low secretor" A allele at the -592 site, but the mortality was higher in patients with the genotype [160]. In contrast, no association was observed in a cohort of adult critically ill patients between the IL-10 haplotypes and either serum IL-10 levels or mortality [164]. The conflicting results in these studies may be due to the types of patients enrolled in the studies as some cohorts had ongoing infectious processes [159], while other cohorts had a variety of illnesses not restricted to infectious etiologies [164]. Thus, additional association studies between the IL-10 
regulatory polymorphisms and outcome are warranted to further delineate the influence of these genetic variations in sepsis.

\section{EFFECTOR MOLECULES INVOLVED IN THE IMMUNE RESPONSE}

A number of other molecular and cellular systems enhance the host response to severe infections. The following section reviews the evidence that genetic polymorphisms in genes coding for other effector molecules influence the susceptibility to and outcome from sepsis.

\section{$F c \gamma \rho \varepsilon \chi \varepsilon \pi \tau o \rho \sigma \forall$}

Fcy receptors are glycoproteins located on the cell membrane of leukocytes that link the humoral and cellular components of the immune system by binding to the constant region of $\mathrm{IgG}$ and triggering a number of effector functions including phagocytosis of IgG-coated bacteria and induction of an inflammatory response $[165,166]$. Three classes of human Fcy receptors exist: the FcyRI class consisting of the Fc $\gamma$ RIa receptor, the Fc $\gamma$ RII class consisting of Fc $\gamma$ RIIa, Fc $\gamma$ RIIb, Fc $\gamma$ RIIc receptors, and the Fc $\gamma$ RIII class consisting of Fc $\gamma$ RIIIa and Fc $\gamma$ RIIIb receptors. The cellular distribution and affinity of these receptors for the various subclasses of IgG vary.

Genetic variations including single nucleotide polymorphisms and copy number variants (CNV) that influence receptor function have been described in the genes coding for Fcy receptors [166-168]. The FcrRIIIa gene has a T to G substitution at nucleotide 559 that results in a valine $(\mathrm{V})$ or phenylalanine $(\mathrm{F})$ at amino acid 158 , which in turn affects its affinity for $\operatorname{IgG}_{1}, \operatorname{IgG}_{3}$ and $\operatorname{IgG}_{4}[167,169]$. NK cell activity is increased in individuals homozygous for the $\mathrm{V}$ at this position compared with those individuals with the $\mathrm{F}$. The FcrRIIIb gene has a polymorphism in the extracellular domain that results in a four amino acid substitution in the Fc $\gamma$ RIIIb protein (allotypes Fc $\gamma$ RIIIb-NA1 or -NA2). These amino acid substitutions result in differences in FcyRIIIb receptor glycosylation [170] and efficacy of phagocytosis of $\mathrm{IgG}_{1}$ and $\mathrm{IgG}_{3}$-opsonized particles. Individuals homozygous for the FcrRIIIb-NA1 allotype appear to have more efficient phagocytosis than individuals with the FcyRIIIb-NA2 allotype [171, 172]. The gene coding for the FcrRIIa receptor displays a $G$ to $A$ nucleotide substitution that changes an arginine at amino acid position 131 (R131 allotype) in the extracellular domain of the receptor to a histidine (H131 allotype). The functional significance of this change is that the FcrRIIa-R131 allotype binds the Fc portion of $\mathrm{IgG}_{2}$ with lower affinity than the more common FcrRIIa-H131 allotype [173-175]. The FcyRIIa receptor is the only $\mathrm{Fc} \gamma \mathrm{R}$ able to bind efficiently to the $\mathrm{IgG}_{2}$ subclass; hence, the FcyRIIa genotype determines an individual's ability to bind $\mathrm{IgG}_{2}$. The functional consequence of this genetic variation is demonstrated in in vitro studies that demonstrate reduced phagocytosis of $\mathrm{IgG}_{2}$ opsonized particles in cells from individuals homozygous for Fc $\gamma$ RIIaR131 compared to cells from individuals homozygous for FcyRIIa-H131 [176, 177]. As $\operatorname{IgG}_{2}$ is the main antibody subtype directed against encapsulated bacteria such as Streptococcus pneumoniae, Haemophilus influenzae type b, and Neisseria meningitides and plays an important role in their phagocytosis, one could speculate that individuals with the FcyRIIa-R131 polymorphism may have more severe infections due to these bacteria.

Genetic association studies have suggested that the Fc $\gamma$ RIIa-R131 and/or the FcyRIIIb-NA2 polymorphisms are associated with an increased susceptibility to infections by encapsulated bacteria. Most studies have demonstrated higher frequencies of the Fc $\gamma$ RIIa-R131/R131 or Fc $\gamma R I I I b-$ NA2/NA2 genotypes in patients with meningococcal disease [178-184] particularly in patients with severe meningococcal disease or fulminant meningococcal septic shock. The FcyRIIa polymorphism has also been demonstrated to be associated with infections due to other encapsulated bacteria $[185,186]$. However, not all such studies have reported an association $[187,188]$.

\section{Bactericidal Permeability Increasing Protein (BPI)}

Several proteins bind bacterial toxins and play important roles in intracellular signaling that result in an appropriate response to pathogens. One example is BPI, a component of the azurophilic granules of neutrophils that binds the lipid A portion of LPS thereby attenuating the LPS-stimulated response [189]. BPI is also bactericidal against gramnegative bacteria [190] and increases the permeability of the bacterial cell membrane [191]. Administration of LPS to healthy adults increases BPI, and elevated serum levels of BPI are found in adults with sepsis [192]. The gene coding BPI contains a number of genetic polymorphisms including a $\mathrm{G}$ to $\mathrm{C}$ substitution at position 545 and an $\mathrm{A}$ to $\mathrm{G}$ substitution at position 645 . The $\mathrm{G} 545 \mathrm{C}$ variation is silent in that there is no change in the amino acid sequence of the final BPI protein. The $\mathrm{A} 645 \mathrm{G}$, however, changes a lysine at amino acid position 216 to glutamic acid. The gene coding for LBP also contains several genetic variations including a $T$ to $G$ at nucleotide position 292 and $\mathrm{C}$ to $\mathrm{T}$ at nucleotide position 1306 thereby changing the amino acids cysteine at postion 98 to glycine and proline at positon 436 to leucine, respectively [193].

Genetic association studies include a large cohort of critically ill children with either gram-negative or grampositive infections in which the $\mathrm{G}$ allele at 545 but not the variation at position 645 was associated with sepsis when compared with healthy controls. When only those children with gram-negative infections were analyzed, a significant association between children with the GG genotype at 545 and the AG or GG genotype at 645 with the development of sepsis was identified [194]. A similar study in adults with sepsis did not find such an association in the gene coding for BPI but did find that the rarer alleles in the LBP gene were associated with sepsis; furthermore, males who were homozygous for either of the rarer LBP had a worse outcome [195]. It should be pointed out that despite the G545C polymorphism not resulting in a change in the amino acid sequence of the BPI protein, it may be in linkage disequilibrium with some as of yet unidentified variation that may be the causative or function variation. No similar studies have been performed in children with sepsis.

\section{Heat Shock Proteins (HSP)}

Heat shock proteins (HSP) are a highly conserved family of stress-inducible proteins that play a key role as intracellular chaperones to a variety of proteins; that is, they 
prevent proteins from aggregating into nonfunctional complexes during stress. They are produced in response to heat, endotoxin, and other noxious stimuli [196]. These proteins are essential for cell survival during stress [197] and are involved in a number of important cellular functions including the folding, assembly, and translocation of proteins across membranes [198, 199]. One such HSP, HSP70, also appears to act as an inhibitor of cytokines and other inflammatory mediators produced via the NFKB pathway [200]. The 3 genes coding for family of HSP70 genes (HSPA1B, HSPA1A, and HASA1L) lie in the major histocompatibility complex III region on chromosome 6 near the genes coding for TNF- $\alpha$ and complement [201, 202]. Polymorphisms have been described in the gene coding for the HSPA1B that appear to influence the amount of HSP produced [203]. The A allele at the +1267 position appears to be in strong linkage disequilibrium with the $\mathrm{C}$ allele at position -179 , and the $-179 \mathrm{C} /+1267 \mathrm{~A}$ haplotype is associated with significantly lower production of HSPA1B and TNF- $\alpha$ in response to LPS when compared with other haplotypes $[204,205]$. While no association between the genotypes at the +1267 site and susceptibility to, or outcome from, severe sepsis was demonstrated in adult surgical patients [206], we have demonstrated that in adults with community-acquired pneumonia, those individuals with the AA genotype at the +1267 site were at greater risk for septic shock but not increased mortality than those individuals who were either heterozygous or homozygous for the more common $\mathrm{G}$ allele [98]. Further studies examining genetic variations in the HSP family of genes in children with sepsis are currently being performed.

\section{Dimethylarginine Dimethylaminohydrolase (DDAH)}

Endothelium-derived nitric oxide (NO) is a potent vasodilator synthesized from L-arginine by the enzyme nitric oxide synthase (NOS) and has been implicated in the pathophysiology of the hypotension observed in severe sepsis [207]. DDAH metabolizes asymmetrical dimethyl arginine (ADMA), a naturally occurring inhibitor of NOS, to citrulline [208]. Variation in the gene coding for DDAH may, therefore, alter the amount of the inhibitor available for NOS. Elevated ADMA is associated with more severe organ failure in patients with sepsis [209, 210]. Genetic variations the gene coding for DDAH have been found including polymorphisms in the promoter region that appear to influence transcription of DDAH [211]. In a small cohort of adults with severe sepsis, the frequency of the $G$ allele at position -449 in the promoter region was greater in those adults with severe sepsis compared with healthy controls, and serum levels of the inhibitor, ADMA, were elevated [212].

\section{Angiotensin I Converting Enzyme}

Angiotensin I converting enzyme (ACE) is found on both endothelial and epithelial cells of various organs and is primarily responsible for converting angiotensin $\mathrm{I}$ to angiotensin II. ACE is also involved in the metabolism of chemotactic peptides suggesting that it may play a role in the inflammatory response. Individuals have been shown to have variable plasma and tissue levels of ACE, and evidence suggests that these variable levels are due in part to genetic factors [213]. Specifically, an insertion (I)/deletion (D) of a
287 base repair repeat sequence in the noncoding intron 16 of the gene coding for ACE [214] is associated with variable plasma levels; individuals homozygous for the deletion genotype (DD) have higher plasma and tissue levels of ACE compared with individuals who are homozygous for the insertion sequence (II) or are heterozygous (DI) [215, 216]. The mechanism by which the deletion of this sequence is associated with increased ACE levels is still controversial [217, 218] but may involve transcriptional regulation [219]. The deletion of the sequence may increase transcription by removing a binding site for a transcription repressor.

The association of the ACE I/D polymorphism with clinical outcomes in sepsis has been examined in a few studies. The D/D polymorphism was associated with more severe meningococcal disease in children as measured by a higher predicted risk of mortality, greater prevalence of inotropic support and mechanical ventilation, and longer intensive care unit stay [220]. In addition, the frequency of the $\mathrm{D} / \mathrm{D}$ genotype was more frequent in those children who died compared with survivors, though this did not reach statistical significance. In contrast, no significant difference was observed either in the susceptibility to blood stream infection or sepsis-related mortality in of mechanically ventilated infants [221] or mortality from sepsis in adults [222].

\section{Other Mediators and Factors Involved in the Inflammatory Response}

Many other factors are involved in the host response to infections, and investigators are beginning to examine whether genetic variations in the genes coding for these factors also influence the susceptibility to or outcome from sepsis. Some of these are briefly mentioned here.

Macrophage migration inhibitory factor (MIF) is produced by a number of cell types and plays an important role in the pathogenesis of acute and chronic inflammatory and autoimmune disorders. In addition to stimulating both TNF- $\alpha$ and IL-8, it is able to override the anti-inflammatory and immunosupprossive effects of glucocorticoids [223225]. Serum MIF levels are elevated in sepsis and correlate with severity of disease [226, 227]. Haplotypes in the gene coding for MIF but not individual SNPs are associated with sepsis in both a Caucasian and African American population of adults [228].

While interferon-gamma (IFN $\gamma$ ) is primarily involved in the host defense against viral infections, it also modulates components of the inflammatory response in response to bacterial toxins such as LPS. Co-stimulation of peripheral blood mononuclear cells with TNF- $\alpha$ and INF $\gamma$ increases expression of complement factor $\mathrm{B}$ which is involved in activating the alternative complement pathway that plays a role in inflammation, bacterial cytotoxicity, and phagocytosis [229]. Genetic variations in the gene coding for INF $\gamma$ are associated with elevated levels of INF $\gamma$ [230, 231] and the development of sepsis in adult trauma patients [232].

Mitochondrial energy production is crucial during sepsis in order to maintain normal cellular functions as well as mount an effective immune response. Recently, a genetic variation in mitochondrial gene NADH dehydrogenase 1 (ND1) believed to impair ATP production [233] has been associated with susceptibility to infectious complications and 
mortality in a cohort of adult trauma [234] and burn patients [235].

\section{GENETIC VARIATION IN THE HOST COAGULA- TION SYSTEM}

Derangement of the coagulation system leading to intravascular fibrin deposition is a key contributor to the pathogenesis of multi-organ failure in sepsis [236]. Plasma levels and activity of procoagulants such as tissue factor and inhibitors of fibrinolysis such as plasminogen activator inhibitor 1 (PAI-1) are elevated [237-239] while levels and activity of anticoagulants such as antithrombin III and protein $\mathrm{S}$ are low and activation of protein $\mathrm{C}$ is impaired $[240,241]$. Thus, a procoagulant environment exists within the intravascular space.

There is significant crosstalk between inflammation and coagulation. Activation of the coagulation cascade, leads to inflammatory events. Coagulation of blood in vitro increases the concentrations of IL-6, IL-8, and TNF- by release of these cytokines from peripheral blood monocytes and endothelial cells [242-245]. In animal models of septic shock, lack of tissue factor, an endogenous activator of coagulation, leads to decreased mortality [246], whereas deficiency of thrombomodulin [247] and components of the protein $\mathrm{C}$ pathway, which is an endogenous regulator of coagulation, leads to increased mortality. Common genetic variations within genes of the coagulation cascade and the protein $\mathrm{C}$ pathway have been well characterized and a number of single nucleotide polymorphisms (SNPs) and haplotypes in these genes are known to alter levels of their respective mediators [248]. Therefore, it is biologically plausible that some of these polymorphisms are associated with clinical outcomes in sepsis. A few examples demonstrating the influence of genetic variation on the severity of sepsis in genes coding for components of the coagulation pathway will be discussed below.

\section{Protein C}

Endogenous protein $\mathrm{C}$ levels are depressed in patients with severe sepsis, and plasma protein $\mathrm{C}$ levels inversely correlate with morbidity and outcome of sepsis patients, regardless of age, infecting microorganisms, presence of shock, or severity of illness. Low plasma protein C levels have been correlated with increased severity of illness and poor outcome in adults and children with meningococcal sepsis $[249,250]$. Administration of activated protein C leads to a reduction in mortality in adults with sepsis [251].

The human protein $\mathrm{C}$ gene resides on chromosome $2 \mathrm{q} 13-$ 14 and several genetic variations have been described within the coding and regulatory regions. For example, two polymorphic sites, $-1654 \mathrm{CT}$ and $-1641 \mathrm{AG}$, are located in the $5^{\prime}$ untranslated region of the gene [252] that have an effect on transcription and protein C plasma levels [252-254]. Haplotypes based on these two polymorphisms have been demonstrated to not only be associated with plasma protein C levels, but also with severity of sepsis in children. In a multi-center study, haplotypes based on these two polymorphisms were examined in children with meningococcemia and compared to a group of healthy controls [255]. The CG haplotype was more frequent among patients with meningococcemia as compared to healthy controls.
Among patients with meningococcemia, those carrying the CG genotype had higher odds of developing sepsis, lower systolic blood pressure, and higher need for adrenergic support [255]. Therefore, the protein C promoter SNPs were not only associated with increased susceptibility to meningococcal infection, but also with severity of the disease.

Other studies also support the influence of these genetic polymorphisms on the severity of sepsis. In a cohort of Han Chinese patients with severe sepsis, the CA haplotype of the protein $\mathrm{C}$ promoter has been demonstrated to be associated with increased risk for death and organ dysfunction [256]. In contrast, the haplotypes of these two polymorphisms were not associated with the severity of sepsis in a Caucasian adult cohort. The AA genotype of the -1641AG polymorphism was associated with decreased 28-day survival in an initial derivation cohort, and in a larger replication cohort. In addition, the protein C -1641 AA genotype was also associated with significantly more organ dysfunction and more clinical evidence of systemic inflammation in patients undergoing cardiopulmonary bypass [257]. A study of North American East Asians with severe sepsis demonstrated that the $\mathrm{C}$ allele of a C/A SNP at the 673 position was found to be associated with increased mortality and organ dysfunction [258]. Interestingly, the SNP is in complete linkage disequilibrium with the CA haplotype [258].

Thus, genetic variations in protein $\mathrm{C}$ gene appear to be associated with clinical outcomes in sepsis. The differences in the specific haplotypes and genotypes associated with outcomes in each of these studies can be attributed to the varying allele frequencies of these SNPs among the ethnic groups studied. The results of these studies also suggest that the association of decreased plasma protein $\mathrm{C}$ levels with clinical outcomes in sepsis may be partly due to the underlying genetic differences among individuals. It is therefore plausible that the response to treatment with activated protein $\mathrm{C}$ among patients with sepsis may be governed in part by the underlying genotype. Studying these genotype-treatment interactions in future trials of activated protein $\mathrm{C}$ in sepsis may lead to identification of the patient groups most likely to benefit from activated protein $\mathrm{C}$ treatment.

\section{Fibrinogen}

Fibrinogen and fibrinogen degradation products are potent chemo-attractants and induce release of interleukin- 8 from neutrophils [259-261]. Fibrinogen also increases binding of neutrophils to endothelial cells through ICAM-1, thereby increasing neutrophil migration [262, 263]. Genetic factors are believed to contribute up to $50 \%$ of the total variability in fibrinogen plasma levels [264] and appear to be associated with more severe sepsis. For example, the GAA haplotype in the gene coding for the fibrinogen beta chain defined by SNPs at positions $-854,-455$, and +9006 is associated with a lower mortality and trend towards less organ dysfunction in Caucasian patients with sepsis. The association with lower mortality is independent of age and APACHE II score at admission [265]. The association with reduced mortality may be related to the increased fibrinogen 
Table 1. Genetic Polymorphisms Involved in Sepsis

\begin{tabular}{|c|c|c|c|}
\hline Gene & Polymorphisms & Consequence of polymorphism & Ref. \\
\hline TLR4 & $\begin{array}{l}\text { asp299Gly } \\
\text { thr399Ile }\end{array}$ & $\begin{array}{l}\text { 299Gly/399Ile associated with decreased expression of TLR4 and } \\
\text { response to LPS, and increased risk of sepsis and mortality }\end{array}$ & {$[18,19,21-26]$} \\
\hline CD-14 & $-159 \mathrm{C} / \mathrm{T}$ & $\begin{array}{l}\mathrm{T} \text { allele associated with increased levels of CD-14, increased } \\
\text { susceptibility to sepsis, and increased mortality in adults with sepsis }\end{array}$ & {$[33,41-44]$} \\
\hline MD-2 & $\begin{array}{l}+103 \mathrm{~A} / \mathrm{G}(\text { thr35ala }) \\
-1625 \mathrm{C} / \mathrm{G}\end{array}$ & $\begin{array}{l}+103 \mathrm{G} \text { allele associated with increased TNF- } \alpha ;-1625 \mathrm{G} \text { allele } \\
\text { associated with increased MD-2 mRNA and TNF- } \alpha \text { and increased } \\
\text { risk of sepsis and multiple organ dysfunction in Chinese adults; }\end{array}$ & {$[47,48]$} \\
\hline IRAK-1 & $+1595 \mathrm{~T} / \mathrm{C}$ & $\begin{array}{l}\mathrm{C} \text { associated with increased NF-KB translocation, increased risk of } \\
\text { pneumococcal sepsis and mortality }\end{array}$ & {$[50]$} \\
\hline NK-IKB & $\begin{array}{l}\text { rs } 3138053 \\
\text { rs2233406 }\end{array}$ & $\begin{array}{l}\text { Less common alleles associated with decreased risk of invasive } \\
\text { pneumococcal disease }\end{array}$ & {$[51]$} \\
\hline MBL & variant $\mathrm{B}, \mathrm{C}, \mathrm{D}$ & $\begin{array}{l}\text { variants associated with decreased levels and activity and increased } \\
\text { risk of meningococcal and pneumococcal infections }\end{array}$ & $\begin{array}{l}{[64,66-69,71,} \\
74,278]\end{array}$ \\
\hline IL-1 $\alpha$ & $-889 \mathrm{C} / \mathrm{T}$ & $\mathrm{T}$ associated with increased IL- $1 \alpha$ transcription and protein levels & {$[109,110]$} \\
\hline IL-1 $\beta$ & $\begin{array}{l}-3737 \mathrm{C} / \mathrm{T} \\
-1464 \mathrm{G} / \mathrm{C} \\
-511 \mathrm{C} / \mathrm{T} \\
-31 \mathrm{~T} / \mathrm{C}\end{array}$ & $\begin{array}{l}\text { Various haplotypes associated with variable IL-1 } \beta \text { levels [112] (see } \\
\text { for review) }\end{array}$ & [112-114] \\
\hline IL-1 ra & $\begin{array}{l}\text { variable } 86 \text {-bp repeat } \\
\quad+2018 \text { "2 allele" }\end{array}$ & $\begin{array}{l}\text { A2 allele associated with variable levels of IL- } 1_{\mathrm{RA}} ; \mathrm{A} 2 \text { associated with } \\
\text { increased risk of in adults but not children with sepsis; A2 associated } \\
\text { with increased mortality in adults with sepsis; }+2018 \text { " } 2 \text { allele" } \\
\text { associated with increased mortality in children with meningococcal } \\
\text { disease and more severe lung disease in children with pneumonia }\end{array}$ & $\begin{array}{c}{[120,122,125-} \\
128]\end{array}$ \\
\hline IL-6 & $-174 \mathrm{G} / \mathrm{C}$ & $\begin{array}{l}\mathrm{G} \text { associated with increased IL-6 levels in adult patients but decreased } \\
\text { levels in neonates; C associated with increased levels in monocytes } \\
\text { from neonates, sepsis in neonates, and severe sepsis and organ } \\
\text { dysfunction in children }\end{array}$ & $\begin{array}{l}{[130,142-146,} \\
281]\end{array}$ \\
\hline
\end{tabular}


Table 1. Contd...

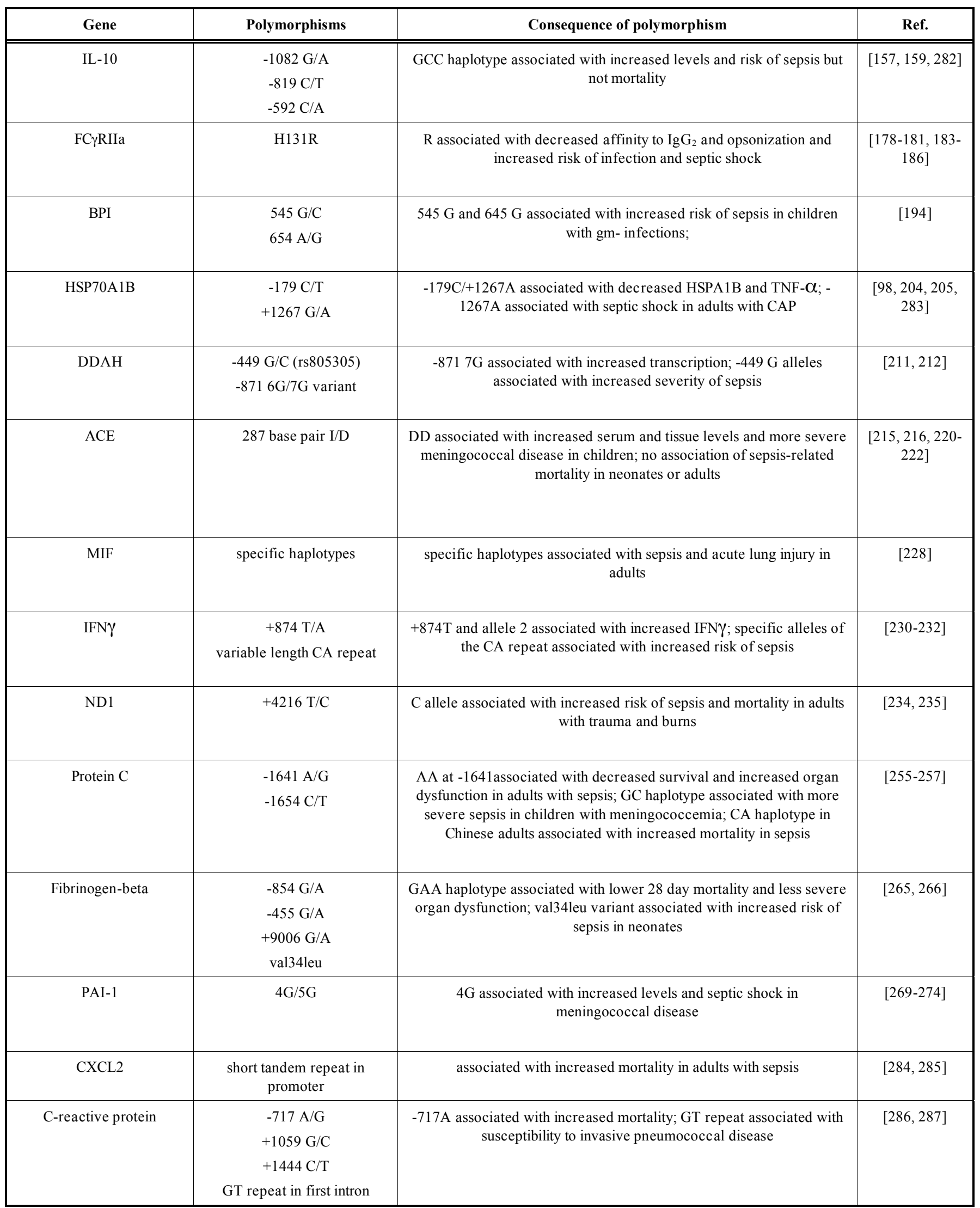


levels among patients with the GAA haplotype since the -455 A allele within the haplotype is associated with increased transcription. Another polymorphism in the fibrinogen gene, the Val34Leu polymorphism is known to alter the fibrin meshwork with variable permeation characteristics. In a multi-center study, carriage of the factor XIII-Val34Leu polymorphism was associated with a higher rate of sepsis among very low birth babies of mixed European descent [266]. While the exact mechanism for this association is not known, the authors suggest that the alteration in fibrinogen structure may have potentially resulted in alterations in blood viscosity and increased chemo attraction of inflammatory cells.

\section{Plasminogen Activator Inhibitor-1(PAI-1)}

Plasminogen activator inhibitor 1 (PAI-1) is the primary inhibitor of plasminogen activator, the proteolytic activator of plasminogen; hence, PAI-1 is a potent inhibitor of fibrinolysis. A single nucleotide insertion/deletion polymorphism exists within the promoter region of the PAI1 gene that is involved in the regulation of PAI-1 gene expression. In vitro studies have demonstrated that the allele consisting of 4 guanines $(4 \mathrm{G})$ is associated with 6 times more PAI- 1 mRNA than the allele consisting of 5 guanines (5G) in response to IL-1 $\beta$ [267]. The higher PAI-1 expression associated with the $4 \mathrm{G}$ allele appears to be due to the inability of a transcriptional repressor protein to bind to the $4 \mathrm{G}$ allele [268]. Individuals homozygous for the $4 \mathrm{G}$ allele produce more PAI-1 than either individuals heterozygous $(4 \mathrm{G} / 5 \mathrm{G})$ or homozygous for the $5 \mathrm{G}$ allele [268]. In children with meningococcal disease, those with the $4 \mathrm{G} / 4 \mathrm{G}$ genotype had higher plasma levels of PAI-1 [269] and a higher mortality compared with children with either the $4 \mathrm{G} / 5 \mathrm{G}$ or $5 \mathrm{G} / 5 \mathrm{G}$ genotypes [269-271]. Other adult and pediatric studies also demonstrate a higher mortality in those individuals homozygous for the $4 \mathrm{G}$ allele genotype in a variety of infectious diseases [272-274]. In contrast, other studies have not demonstrated a higher mortality in children with meningococcal disease [275] or adults with various gram negative infections [28]. Thus, there appears to be a strong association between the $4 \mathrm{G} / 4 \mathrm{G}$ genotype in the PAI- 1 gene, high plasma concentrations of PAI-1, and higher mortality in sepsis.

\section{LIMITATIONS OF GENETIC ASSOCIATION STUD- IES}

Genetic association studies have several limitations that should be noted and care should be taken when assessing the findings of such studies [276, 277]. One concern that appears in many studies examining whether polymorphisms increase the risk of sepsis, is that the frequency of the polymorphism in the cases (those patients with sepsis) is compared with the frequency of the polymorphism in a healthy control population. However, the control population may not have been exposed to the same pathogens to which the patients with sepsis were exposed. One cannot conclude from such a comparison that the group that developed sepsis was at an increased risk of developing sepsis per se without the control group being similarly exposed. Rather, a more appropriate control group for comparison would be a group of patients with a similar infection who did not develop sepsis. Furthermore, the control group should be of the same ethnicity as the cases. It is now well known that the frequency of many of these polymorphisms varies between ethnic groups and so comparisons should only be made within the same ethnic groups. A second point to keep in mind is that in most cases, investigators describe the association between a specific genetic polymorphism and susceptibility to, or outcome from, sepsis. However, the specific nucleotide variation being investigated may in fact not be involved but rather is in strong linkage disequilibrium with the actual genetic variation causing the association. Third, most studies fail to correct for multiple comparisons; that is, if a study assessed the association of more than 1 genetic variation, then there should be a correction for the increased risk of a false-positive error occurring. Finally, many studies do not discuss the validity of the genotyping technique utilized, what quality control measures were used, and whether those individuals performing the genotyping assays were blinded to the clinical outcomes data of the subjects.

\section{CONCLUSIONS}

In summary, genetic variability in the host appears to play an important role in the severity of sepsis. By altering the ability of the host to recognize a pathogen, or by altering the intensity of the inflammatory response, genetic polymorphisms influence the clinical presentation and outcome of sepsis. In some types of infectious diseases common in intensive care units, genetic polymorphisms may increase the risk of developing more severe sepsis and shock. However, there are few studies in children with sepsis that have been performed to support this notion. These types of studies may not only help better understand why the mortality in sepsis remains high but they may also help identify novel therapeutic targets and identify individual children who are at greater risk for more severe sepsis.

\section{ACKNOWLEDGEMENTS}

Supported in part by the Children's Research Institute and the Medical College of Wisconsin.

\section{REFERENCES}

[1] Casanova JL, Abel L. Genetic dissection of immunity to mycobacteria: the human model. Annu Rev Immunol 2002; 20 : 581-620.

[2] Cooke GS, Hill AV. Genetics of susceptibility to human infectious disease. Nat Rev Genet 2001; 2(12): 967-77.

[3] Hill AV. The genomics and genetics of human infectious disease susceptibility. Annu Rev Genomics Hum Genet 2001; 2: 373-400.

[4] Sorensen TI, Nielsen GG, Andersen PK, Teasdale TW. Genetic and environmental influences on premature death in adult adoptees. N Engl J Med 1988; 318(12): 727-32.

[5] Janeway CA, Jr., Medzhitov R. Innate immune recognition. Annu Rev Immunol 2002; 20: 197-216.

[6] Parrillo JE, Parker MM, Natanson C, et al. Septic shock in humans. Advances in the understanding of pathogenesis, cardiovascular dysfunction, and therapy. Ann Intern Med 1990; 113(3): 227-42.

[7] Parrillo JE. Pathogenetic mechanisms of septic shock. N Engl J Med 1993; 328(20): 1471-7.

[8] Blackwell TS, Christman JW. Sepsis and cytokines: current status. Br J Anaesth 1996; 77(1): 110-7.

[9] Walley KR, Lukacs NW, Standiford TJ, Strieter RM, Kunkel SL. Balance of inflammatory cytokines related to severity and mortality of murine sepsis. Infect Immun 1996; 64(11): 4733-8.

[10] Lemaitre B, Nicolas E, Michaut L, Reichhart JM, Hoffmann JA. The dorsoventral regulatory gene cassette spatzle/Toll/cactus controls the potent antifungal response in Drosophila adults. Cell 1996; 86(6): 973-83. 
[11] Akira S, Uematsu S, Takeuchi O. Pathogen recognition and innate immunity. Cell 2006; 124(4): 783-801.

[12] Beutler B, Jiang Z, Georgel P, et al. Genetic analysis of host resistance: Toll-like receptor signaling and immunity at large. Annu Rev Immunol 2006; 24: 353-89.

[13] Takeda K, Kaisho T, Akira S. Toll-like receptors. Annu Rev Immunol 2003; 21:335-76.

[14] Kumagai Y, Takeuchi O, Akira S. Pathogen recognition by innate receptors. J Infect Chemother 2008; 14(2): 86-92.

[15] Hoshino K, Takeuchi O, Kawai T, et al. Cutting edge: toll-like receptor 4 (TLR4)-deficient mice are hyporesponsive to lipopolysaccharide: evidence for TLR4 as the Lps gene product. J Immunol 1999; 162(7): 3749-52.

[16] Poltorak A, He X, Smirnova I, et al. Defective LPS signaling in $\mathrm{C} 3 \mathrm{H} / \mathrm{HeJ}$ and $\mathrm{C} 57 \mathrm{BL} / 10 \mathrm{ScCr}$ mice: mutations in Tlr4 gene. Science 1998; 282(5396): 2085-8.

[17] Qureshi ST, Lariviere L, Leveque G, et al. Endotoxin-tolerant mice have mutations in Toll-like receptor 4 (Tlr4). J. Exp Med 1999; 189(4): 615-25.

[18] Arbour NC, Lorenz E, Schutte BC, et al. TLR4 mutations are associated with endotoxin hyporesponsiveness in humans. Nat Genet 2000; 25(2): 187-91.

[19] Michel O, LeVan TD, Stern D, et al. Systemic responsiveness to lipopolysaccharide and polymorphisms in the toll-like receptor 4 gene in human beings. J Allergy Clin Immunol 2003; 112(5): 9239.

[20] Schroder NW, Schumann RR. Single nucleotide polymorphisms of Toll-like receptors and susceptibility to infectious disease. Lancet Infect Dis 2005; 5(3): 156-64.

[21] Werner M, Topp R, Wimmer K, et al. TLR4 gene variants modify endotoxin effects on asthma. J Allergy Clin Immunol 2003; 112(2): 323-30.

[22] Agnese DM, Calvano JE, Hahm SJ, et al. Human toll-like receptor 4 mutations but not CD14 polymorphisms are associated with an increased risk of gram-negative infections. J Infect Dis 2002; 186(10): 1522-5.

[23] Lorenz E, Mira JP, Frees KL, Schwartz DA. Relevance of mutations in the TLR4 receptor in patients with gram-negative septic shock. Arch Intern Med 2002; 162(9): 1028-32.

[24] Smirnova I, Mann N, Dols A, et al. Assay of locus-specific genetic load implicates rare Toll-like receptor 4 mutations in meningococcal susceptibility. Proc Natl Acad Sci USA 2003; 100(10): 6075-80.

[25] Child NJ, Yang IA, Pulletz MC, et al. Polymorphisms in Toll-like receptor 4 and the systemic inflammatory response syndrome. Biochem Soc Trans 2003; 31(Pt 3): 652-3.

[26] Barber RC, Chang LY, Arnoldo BD, et al. Innate immunity SNPs are associated with risk for severe sepsis after burn injury. Clin Med Res 2006; 4(4): 250-5.

[27] Feterowski C, Emmanuilidis K, Miethke T, et al. Effects of functional Toll-like receptor-4 mutations on the immune response to human and experimental sepsis. Immunology 2003; 109(3): 42631.

[28] Jessen KM, Lindboe SB, Petersen AL, Eugen-Olsen J, Benfield T. Common TNF-alpha, IL-1 beta, PAI-1, uPA, CD14 and TLR4 polymorphisms are not associated with disease severity or outcome from Gram negative sepsis. BMC Infect Dis 2007; 7: 108.

[29] Read RC, Pullin J, Gregory S, et al. A functional polymorphism of toll-like receptor 4 is not associated with likelihood or severity of meningococcal disease. J Infect Dis 2001; 184(5): 640-2.

[30] Pridmore AC, Wyllie DH, Abdillahi F, et al. A lipopolysaccharidedeficient mutant of Neisseria meningitidis elicits attenuated cytokine release by human macrophages and signals via toll-like receptor (TLR) 2 but not via TLR4/MD2. J Infect Dis 2001; 183(1): 89-96.

[31] Ingalls RR, Lien E, Golenbock DT. Membrane-associated proteins of a lipopolysaccharide-deficient mutant of Neisseria meningitidis activate the inflammatory response through toll-like receptor 2 . Infect Immun 2001; 69(4): 2230-6.

[32] Moore CE, Segal S, Berendt AR, Hill AV, Day NP. Lack of association between Toll-like receptor 2 polymorphisms and susceptibility to severe disease caused by Staphylococcus Aureus. Clin Diagn Lab Immunol 2004; 11(6): 1194-7.

[33] Sutherland AM, Walley KR, Russell JA. Polymorphisms in CD14, mannose-binding lectin, and Toll-like receptor-2 are associated with increased prevalence of infection in critically ill adults. Crit Care Med 2005; 33(3): 638-44.

[34] Ostuni R, Zanoni I, Granucci F. Deciphering the complexity of Toll-like receptor signaling. Cell Mol Life Sci 67(24): 4109-34.

[35] Akira S, Takeda K. Toll-like receptor signalling. Nat Rev Immunol 2004; 4(7): 499-511.

[36] Kawai T, Akira S. The role of pattern-recognition receptors in innate immunity: update on Toll-like receptors. Nat Immunol; 11(5): 373-84.

[37] Moore KJ, Andersson LP, Ingalls RR, et al. Divergent response to LPS and bacteria in CD14-deficient murine macrophages. J Immunol 2000; 165(8): 4272-80.

[38] Nagai Y, Akashi S, Nagafuku M, et al. Essential role of MD-2 in LPS responsiveness and TLR4 distribution. Nat Immunol 2002; 3(7): 667-72.

[39] Unkelbach K, Gardemann A, Kostrzewa M, et al . A new promoter polymorphism in the gene of lipopolysaccharide receptor CD14 is associated with expired myocardial infarction in patients with low atherosclerotic risk profile. Arterioscler Thromb Vasc Biol 1999; 19(4): 932-8.

[40] Baldini M, Lohman IC, Halonen M, et al. A Polymorphism* in the 5' flanking region of the CD14 gene is associated with circulating soluble CD14 levels and with total serum immunoglobulin E. Am J Respir Cell Mol Biol 1999; 20(5): 976-83.

[41] Hubacek JA, Rothe G, Pit'ha J, et al. C(-260)-->T polymorphism in the promoter of the CD14 monocyte receptor gene as a risk factor for myocardial infarction. Circulation 1999; 99(25): 3218-20.

[42] LeVan TD, Bloom JW, Bailey TJ, et al. A common single nucleotide polymorphism in the CD14 promoter decreases the affinity of Sp protein binding and enhances transcriptional activity. J Immunol 2001; 167(10): 5838-44.

[43] Koenig W, Khuseyinova N, Hoffmann MM, et al. CD14 C(-260)-$>\mathrm{T}$ polymorphism, plasma levels of the soluble endotoxin receptor CD14, their association with chronic infections and risk of stable coronary artery disease. J Am Coll Cardiol 2002; 40(1): 34-42.

[44] Gibot S, Cariou A, Drouet L, Rossignol M, Ripoll L. Association between a genomic polymorphism within the CD14 locus and septic shock susceptibility and mortality rate. Crit Care Med 2002; 30(5): 969-73.

[45] Heesen M, Bloemeke B, Schade U, Obertacke U, Majetschak M. The -260 C--> T promoter polymorphism of the lipopolysaccharide receptor CD14 and severe sepsis in trauma patients. Intensive Care Med 2002; 28(8): 1161-3.

[46] Hubacek JA, Stuber F, Frohlich D, et al. The common functional $\mathrm{C}(-159) \mathrm{T}$ polymorphism within the promoter region of the lipopolysaccharide receptor CD14 is not associated with sepsis development or mortality. Genes Immun 2000; 1(6): 405-7.

[47] Hamann L, Kumpf O, Muller M, et al. A coding mutation within the first exon of the human MD-2 gene results in decreased lipopolysaccharide-induced signaling. Genes Immun 2004; 5(4): 283-8.

[48] Gu W, Shan YA, Zhou J, et al. Functional significance of gene polymorphisms in the promoter of myeloid differentiation-2. Ann Surg 2007; 246(1): 151-8.

[49] Khor CC, Chapman SJ, Vannberg FO, et al. A Mal functional variant is associated with protection against invasive pneumococcal disease, bacteremia, malaria and tuberculosis. Nat Genet 2007; 39(4): 523-8.

[50] Arcaroli J, Silva E, Maloney JP, et al. Variant IRAK-1 haplotype is associated with increased nuclear factor-kappaB activation and worse outcomes in sepsis. Am J Respir Crit Care Med 2006; 173(12): 1335-41.

[51] Chapman SJ, Khor CC, Vannberg FO, et al. IkappaB genetic polymorphisms and invasive pneumococcal disease. Am J Respir Crit Care Med 2007; 176(2): 181-7.

[52] Turner MW. Mannose-binding lectin (MBL) in health and disease. Immunobiology 1998; 199(2): 327-39.

[53] Ezekowitz RA, Shi L, Fraser I, Takahashi K. The mannose-binding lectin: an infection susceptibility gene. Adv Exp Med Biol 2005; 560: $99-103$.

[54] Ip WK, Takahashi K, Ezekowitz RA, Stuart LM. Mannose-binding lectin and innate immunity. Immunol Rev 2009; 230(1): 9-21.

[55] Kuhlman M, Joiner K, Ezekowitz RA. The human mannosebinding protein functions as an opsonin. J Exp Med 1989; 169(5): $1733-45$. 
[56] Matsushita M, Endo Y, Fujita T. MASP1 (MBL-associated serine protease 1). Immunobiology 1998; 199(2): 340-7.

[57] Sastry K, Herman GA, Day L, et al. The human mannose-binding protein gene. Exon structure reveals its evolutionary relationship to a human pulmonary surfactant gene and localization to chromosome 10. J Exp Med 1989; 170(4): 1175-89.

[58] Shi L, Takahashi K, Dundee J, et al. Mannose-binding lectindeficient mice are susceptible to infection with Staphylococcus Aureus. J Exp Med 2004; 199(10): 1379-90.

[59] Moller-Kristensen M, Ip WK, Shi L, et al. Deficiency of mannosebinding lectin greatly increases susceptibility to postburn infection with Pseudomonas aeruginosa. J Immunol 2006; 176(3): 1769-75.

[60] Sumiya M, Super M, Tabona P, et al. Molecular basis of opsonic defect in immunodeficient children. Lancet 1991; 337(8757): 156970.

[61] Lipscombe RJ, Sumiya M, Hill AV, et al. High frequencies in African and non-African populations of independent mutations in the mannose binding protein gene. Hum Mol Genet 1992; 1(9): 709-15.

[62] Thiel S, Frederiksen PD, Jensenius JC. Clinical manifestations of mannan-binding lectin deficiency. Mol Immunol 2006; 43(1-2): 8696.

[63] Madsen HO, Garred P, Thiel S, et al. Interplay between promoter and structural gene variants control basal serum level of mannanbinding protein. J Immunol 1995; 155(6): 3013-20.

[64] Hibberd ML, Sumiya M, Summerfield JA, Booy R, Levin M. Association of variants of the gene for mannose-binding lectin with susceptibility to meningococcal disease. Meningococcal Research Group. Lancet 1999; 353(9158): 1049-53.

[65] Faber J, Schuessler T, Finn A, et al. Age-dependent association of human mannose-binding lectin mutations with susceptibility to invasive meningococcal disease in childhood. Pediatr Infect Dis J 2007; 26(3): 243-6.

[66] Frakking FN, Brouwer N, van Eijkelenburg NK, et al. Low mannose-binding lectin (MBL) levels in neonates with pneumonia and sepsis. Clin Exp Immunol 2007; 150(2): 255-62.

[67] Koch A, Melbye M, Sorensen P, et al. Acute respiratory tract infections and mannose-binding lectin insufficiency during early childhood. JAMA 2001; 285(10): 1316-21.

[68] Summerfield JA, Sumiya M, Levin M, Turner MW. Association of mutations in mannose binding protein gene with childhood infection in consecutive hospital series. BMJ 1997; 314(7089): 1229-32.

[69] Gomi K, Tokue Y, Kobayashi T, et al. Mannose-binding lectin gene polymorphism is a modulating factor in repeated respiratory infections. Chest 2004; 126(1): 95-9.

[70] Endeman H, Herpers BL, de Jong BA, et al. Mannose-binding lectin genotypes in susceptibility to community-acquired pneumonia. Chest 2008; 134(6): 1135-40.

[71] Roy S, Knox K, Segal S, et al. MBL genotype and risk of invasive pneumococcal disease: a case-control study. Lancet 2002; 359(9317): 1569-73.

[72] Kronborg G, Weis N, Madsen HO, et al. Variant mannose-binding lectin alleles are not associated with susceptibility to or outcome of invasive pneumococcal infection in randomly included patients. J Infect Dis 2002; 185(10): 1517-20.

[73] Moens L, Van Hoeyveld E, Peetermans WE, et al. Mannosebinding lectin genotype and invasive pneumococcal infection. Hum Immunol 2006; 67(8): 605-11.

[74] Brouwer MC, de Gans J, Heckenberg SG, et al. Host genetic susceptibility to pneumococcal and meningococcal disease: a systematic review and meta-analysis. Lancet Infect Dis 2009; 9(1): 31-44.

[75] Nathan C. Points of control in inflammation. Nature 2002; 420(6917): 846-52.

[76] Cohen J. The immunopathogenesis of sepsis. Nature 2002; 420(6917): 885-91.

[77] Sriskandan S, Altmann DM. The immunology of sepsis. J Pathol 2008; 214(2): 211-23.

[78] Furman WL, Strother D, McClain K, et al. Phase I clinical trial of recombinant human tumor necrosis factor in children with refractory solid tumors: a Pediatric Oncology Group study. J Clin Oncol 1993; 11(11): 2205-10.

[79] Tracey KJ, Beutler B, Lowry SF, et al. Shock and tissue injury induced by recombinant human cachectin. Science 1986; 234(4775): 470-4.
[80] Wheeler AP, Jesmok G, Brigham KL. Tumor necrosis factor's effects on lung mechanics, gas exchange, and airway reactivity in sheep. J Appl Physiol 1990; 68(6): 2542-9.

[81] Selleri C, Sato T, Anderson S, Young NS, Maciejewski JP. Interferon-gamma and tumor necrosis factor-alpha suppress both early and late stages of hematopoiesis and induce programmed cell death. J Cell Physiol 1995; 165(3): 538-46.

[82] van Hinsbergh VW, Bauer KA, Kooistra T, et al. Progress of fibrinolysis during tumor necrosis factor infusions in humans. Concomitant increase in tissue-type plasminogen activator, plasminogen activator inhibitor type-1, and fibrin(ogen) degradation products. Blood 1990; 76(11): 2284-9.

[83] Stuber F, Petersen M, Bokelmann F, Schade U. A genomic polymorphism within the tumor necrosis factor locus influences plasma tumor necrosis factor-alpha concentrations and outcome of patients with severe sepsis. Crit Care Med 1996; 24(3): 381-4.

[84] Pociot F, Briant L, Jongeneel CV, et al. Association of tumor necrosis factor (TNF) and class II major histocompatibility complex alleles with the secretion of TNF-alpha and TNF-beta by human mononuclear cells: a possible link to insulin-dependent diabetes mellitus. Eur J Immunol 1993; 23(1): 224-31.

[85] Appoloni O, Dupont E, Vandercruys M, et al. Association of tumor necrosis factor-2 allele with plasma tumor necrosis factor-alpha levels and mortality from septic shock. Am J Med 2001; 110(6): 486-8.

[86] Louis E, Franchimont D, Piron A, et al. Tumour necrosis factor (TNF) gene polymorphism influences TNF-alpha production in lipopolysaccharide (LPS)-stimulated whole blood cell culture in healthy humans. Clin Exp Immunol 1998; 113(3): 401-6.

[87] Higuchi T, Seki N, Kamizono S, et al. Polymorphism of the 5'flanking region of the human tumor necrosis factor (TNF)-alpha gene in Japanese. Tissue Antigens 1998; 51(6): 605-12.

[88] Wilson AG, di Giovine FS, Blakemore AI, Duff GW. Single base polymorphism in the human tumour necrosis factor alpha (TNF alpha) gene detectable by NcoI restriction of PCR product. Hum Mol Genet 1992; 1(5): 353.

[89] Wilson AG, Symons JA, McDowell TL, McDevitt HO, Duff GW. Effects of a polymorphism in the human tumor necrosis factor alpha promoter on transcriptional activation. Proc Natl Acad Sci USA 1997; 94(7): 3195-9.

[90] McArthur JA, Zhang Q, Quasney MW. Association between the A/A genotype at the lymphotoxin-alpha +250 site and increased mortality in children with positive blood cultures. Pediatr Crit Care Med 2002; 3(4): 341-4.

[91] Kroeger KM, Carville KS, Abraham LJ. The -308 tumor necrosis factor-alpha promoter polymorphism effects transcription. Mol Immunol 1997; 34(5): 391-9.

[92] Fong CW, Siddiqui AH, Mark DF. Characterization of protein complexes formed on the repressor elements of the human tumor necrosis factor alpha gene. J Interferon Cytokine Res 1995; 15(10): 887-95.

[93] Kaluza W, Reuss E, Grossmann S, et al. Different transcriptional activity and in vitro TNF-alpha production in psoriasis patients carrying the TNF-alpha $238 \mathrm{~A}$ promoter polymorphism. J Invest Dermatol 2000; 114(6): 1180-3.

[94] Mira JP, Cariou A, Grall F, et al. Association of TNF2, a TNFalpha promoter polymorphism, with septic shock susceptibility and mortality: a multicenter study. JAMA 1999; 282(6): 561-8.

[95] Nadel S, Newport MJ, Booy R, Levin M. Variation in the tumor necrosis factor-alpha gene promoter region may be associated with death from meningococcal disease. J Infect Dis 1996; 174(4): 87880 .

[96] Majetschak M, Obertacke U, Schade FU, et al. Tumor necrosis factor gene polymorphisms, leukocyte function, and sepsis susceptibility in blunt trauma patients. Clin Diagn Lab Immunol 2002; 9(6): 1205-11.

[97] Waterer GW, Quasney MW, Cantor RM, Wunderink RG. Septic shock and respiratory failure in community-acquired pneumonia have different TNF polymorphism associations. Am J Respir Crit Care Med 2001; 163(7): 1599-604.

[98] Waterer GW, ElBahlawan L, Quasney MW, et al. Heat shock protein 70-2+1267 AA homozygotes have an increased risk of septic shock in adults with community-acquired pneumonia. Crit Care Med 2003; 31(5): 1367-72. 
[99] Gordon AC, Lagan AL, Aganna E, et al. TNF and TNFR polymorphisms in severe sepsis and septic shock: a prospective multicentre study. Genes Immun 2004; 5(8): 631-40.

[100] Stuber F, Udalova IA, Book M, et al. -308 tumor necrosis factor (TNF) polymorphism is not associated with survival in severe sepsis and is unrelated to lipopolysaccharide inducibility of the human TNF promoter. J Inflamm 1995; 46(1): 42-50.

[101] Tang GJ, Huang SL, Yien HW, et al. Tumor necrosis factor gene polymorphism and septic shock in surgical infection. Crit Care Med 2000; 28(8): 2733-6.

[102] Schroder J, Kahlke V, Book M, Stuber F. Gender differences in sepsis: genetically determined? Shock 2000; 14(3): 307-10; discussion 310-3.

[103] Weitkamp JH, Stuber F, Bartmann P. Pilot study assessing TNF gene polymorphism as a prognostic marker for disease progression in neonates with sepsis. Infection 2000; 28(2): 92-6.

[104] Dinarello CA, Wolff SM. The role of interleukin-1 in disease. N Engl J Med 1993; 328(2): 106-13.

[105] Dinarello CA. Proinflammatory and anti-inflammatory cytokines as mediators in the pathogenesis of septic shock. Chest 1997; 112 (6 Suppl): 321S-329S.

[106] Arend WP, Malyak M, Guthridge CJ, Gabay C. Interleukin-1 receptor antagonist: role in biology. Annu Rev Immunol 1998; 16: $27-55$.

[107] van Deuren M, van der Ven-Jongekrijg J, Vannier E, et al. The pattern of interleukin-1beta (IL-1beta) and its modulating agents IL-1 receptor antagonist and IL-1 soluble receptor type II in acute meningococcal infections. Blood 1997; 90(3): 1101-8.

[108] Bailly S, di Giovine FS, Blakemore AI, Duff GW. Genetic polymorphism of human interleukin-1 alpha. Eur J Immunol 1993; 23(6): 1240-5.

[109] Dominici R, Cattaneo M, Malferrari G, et al. Cloning and functional analysis of the allelic polymorphism in the transcription regulatory region of interleukin-1 alpha. Immunogenetics 2002; 54(2): 82-6.

[110] Shirodaria S, Smith J, McKay IJ, Kennett CN, Hughes FJ. Polymorphisms in the IL-1A gene are correlated with levels of interleukin-1alpha protein in gingival crevicular fluid of teeth with severe periodontal disease. J Dent Res 2000; 79(11): 1864-9.

[111] Bensen JT, Langefeld CD, Li L, et al. Association of an IL-1A 3'UTR polymorphism with end-stage renal disease and IL-1 alpha expression. Kidney Int 2003; 63(4): 1211-9.

[112] Chen H, Wilkins LM, Aziz N, et al. Single nucleotide polymorphisms in the human interleukin-1B gene affect transcription according to haplotype context. Hum Mol Genet 2006; 15(4): 519-29.

[113] Pociot F, Molvig J, Wogensen L, Worsaae H, Nerup J. A TaqI polymorphism in the human interleukin-1 beta (IL-1 beta) gene correlates with IL-1 beta secretion in vitro. Eur J Clin Invest 1992; 22(6): 396-402.

[114] di Giovine FS, Takhsh E, Blakemore AI, Duff GW. Single base polymorphism at -511 in the human interleukin-1 beta gene (IL1 beta). Hum Mol Genet 1992; 1(6): 450.

[115] Cox A, Camp NJ, Nicklin MJ, di Giovine FS, Duff GW. An analysis of linkage disequilibrium in the interleukin-1 gene cluster, using a novel grouping method for multiallelic markers. Am J Hum Genet 1998; 62(5): 1180-8.

[116] Danis VA, Millington M, Hyland VJ, Grennan D. Cytokine production by normal human monocytes: inter-subject variation and relationship to an IL-1 receptor antagonist (IL-1Ra) gene polymorphism. Clin Exp Immunol 1995; 99(2): 303-10.

[117] Hurme M, Santtila S. IL-1 receptor antagonist (IL-1Ra) plasma levels are co-ordinately regulated by both IL-1Ra and IL-1beta genes. Eur J Immunol 1998; 28(8): 2598-602.

[118] Santtila S, Savinainen K, Hurme M. Presence of the IL-1RA allele $2(\mathrm{IL} 1 \mathrm{RN} * 2)$ is associated with enhanced IL-1beta production in vitro. Scand J Immunol 1998; 47(3): 195-8.

[119] Tarlow JK, Blakemore AI, Lennard A, et al. Polymorphism in human IL-1 receptor antagonist gene intron 2 is caused by variable numbers of an 86-bp tandem repeat. Hum Genet 1993; 91(4): 4034.

[120] Fang XM, Schroder S, Hoeft A, Stuber F. Comparison of two polymorphisms of the interleukin-1 gene family: interleukin-1 receptor antagonist polymorphism contributes to susceptibility to severe sepsis. Crit Care Med 1999; 27(7): 1330-4.
[121] Arend WP. The balance between IL-1 and IL-1Ra in disease. Cytokine Growth Factor Rev 2002; 13(4-5): 323-40.

[122] Arnalich F, Lopez-Maderuelo D, Codoceo R, et al. Interleukin-1 receptor antagonist gene polymorphism and mortality in patients with severe sepsis. Clin Exp Immunol 2002; 127(2): 331-6.

[123] El-Omar EM, Carrington M, Chow WH, et al. Interleukin-1 polymorphisms associated with increased risk of gastric cancer. Nature 2000; 404(6776): 398-402.

[124] Witkin SS, Gerber S, Ledger WJ. Influence of interleukin-1 receptor antagonist gene polymorphism on disease. Clin Infect Dis 2002; 34(2): 204-9.

[125] Patwari PP, O'Cain P, Goodman DM, et al. Interleukin-1 receptor antagonist intron 2 VNTR polymorphism and respiratory failure in children with community acquired pneumonia. Ped Crit Care Med 2008; 9(6): 553-9.

[126] Ma P, Chen D, Pan J, Du B. Genomic polymorphism within interleukin-1 family cytokines influences the outcome of septic patients. Crit Care Med 2002; 30(5): 1046-50.

[127] Carrol ED, Mobbs KJ, Thomson AP, Hart CA. Variable number tandem repeat polymorphism of the interleukin-1 receptor antagonist gene in meningococcal disease. Clin Infect Dis 2002; 35(4): 495-7.

[128] Read RC, Cannings C, Naylor SC, et al. Variation within genes encoding interleukin-1 and the interleukin-1 receptor antagonist influence the severity of meningococcal disease. Ann Intern Med 2003; 138(7): 534-41.

[129] Hack CE, De Groot ER, Felt-Bersma RJ, et al. Increased plasma levels of interleukin-6 in sepsis. Blood 1989; 74(5): 1704-10.

[130] Schluter B, Konig B, Bergmann U, Muller FE, Konig W. Interleukin 6--a potential mediator of lethal sepsis after major thermal trauma: evidence for increased IL-6 production by peripheral blood mononuclear cells. J Trauma 1991; 31(12): 166370 .

[131] Schluter B, Raufhake C, Erren M, et al. Effect of the interleukin-6 promoter polymorphism $(-174 \mathrm{G} / \mathrm{C})$ on the incidence and outcome of sepsis. Crit Care Med 2002; 30(1): 32-7.

[132] Casey LC, Balk RA, Bone RC. Plasma cytokine and endotoxin levels correlate with survival in patients with the sepsis syndrome. Ann Intern Med 1993; 119(8): 771-8.

[133] Pinsky MR, Vincent JL, Deviere J, Alegre M, Kahn RJ, Dupont E. Serum cytokine levels in human septic shock. Relation to multiplesystem organ failure and mortality. Chest 1993; 103(2): 565-75.

[134] Martin C, Boisson C, Haccoun M, Thomachot L, Mege JL. Patterns of cytokine evolution (tumor necrosis factor-alpha and interleukin6) after septic shock, hemorrhagic shock, and severe trauma. Crit Care Med 1997; 25(11): 1813-9.

[135] Harbarth S, Holeckova K, Froidevaux C, et al. Diagnostic value of procalcitonin, interleukin-6, and interleukin-8 in critically ill patients admitted with suspected sepsis. Am J Respir Crit Care Med 2001; 164(3): 396-402.

[136] Pettila V, Hynninen M, Takkunen O, Kuusela P, Valtonen M. Predictive value of procalcitonin and interleukin 6 in critically ill patients with suspected sepsis. Intensive Care Med 2002; 28(9): 1220-5.

[137] Ventetuolo CE, Levy MM. Biomarkers: diagnosis and risk assessment in sepsis. Clin Chest Med 2008; 29(4): 591-603, vii.

[138] Terry CF, Loukaci V, Green FR. Cooperative influence of genetic polymorphisms on interleukin 6 transcriptional regulation. J Biol Chem 2000; 275(24): 18138-44.

[139] Fishman D, Faulds G, Jeffery R, et al. The effect of novel polymorphisms in the interleukin-6 (IL-6) gene on IL-6 transcription and plasma IL-6 levels, and an association with systemic-onset juvenile chronic arthritis. J Clin Invest 1998; 102(7): 1369-76.

[140] Tischendorf JJ, Yagmur E, Scholten D, et al. The interleukin-6 (IL6)-174 G/C promoter genotype is associated with the presence of septic shock and the ex vivo secretion of IL6. Int J Immunogenet 2007; 34(6): 413-8.

[141] Kilpinen S, Hulkkonen J, Wang XY, Hurme M. The promoter polymorphism of the interleukin-6 gene regulates interleukin-6 production in neonates but not in adults. Eur Cytokine Netw 2001; 12(1): $62-8$.

[142] Sutherland AM, Walley KR, Manocha S, Russell JA. The association of interleukin 6 haplotype clades with mortality in critically ill adults. Arch Intern Med 2005; 165(1): 75-82. 
[143] Harding D, Dhamrait S, Millar A, et al. Is interleukin-6 -174 genotype associated with the development of septicemia in preterm infants? Pediatrics 2003; 112(4): 800-3.

[144] Ahrens P, Kattner E, Kohler B, et al. Mutations of genes involved in the innate immune system as predictors of sepsis in very low birth weight infants. Pediatr Res 2004; 55(4): 652-6.

[145] Baier RJ, Loggins J, Yanamandra K. IL-10, IL-6 and CD14 polymorphisms and sepsis outcome in ventilated very low birth weight infants. BMC Med 2006; 4: 10.

[146] Chauhan M, McGuire W. Interleukin-6 (-174C) polymorphism and the risk of sepsis in very low birth weight infants: meta-analysis. Arch Dis Child Fetal Neonatal Ed 2008; 93(6): F427-9.

[147] van Der Poll T, Marchant A, van Deventer SJ. The role of interleukin-10 in the pathogenesis of bacterial infection. Clin Microbiol Infect 1997; 3(6): 605-607.

[148] Opal SM, DePalo VA. Anti-inflammatory cytokines. Chest 2000; 117(4): 1162-72.

[149] de Waal Malefyt R, Abrams J, Bennett B, Figdor CG, de Vries JE. Interleukin 10(IL-10) inhibits cytokine synthesis by human monocytes: an autoregulatory role of IL-10 produced by monocytes. J Exp Med 1991; 174(5): 1209-20.

[150] Moore KW, de Waal Malefyt R, Coffman RL, O'Garra A. Interleukin-10 and the interleukin-10 receptor. Annu Rev Immunol 2001; 19: 683-765.

[151] Howard M, Muchamuel T, Andrade S, Menon S. Interleukin 10 protects mice from lethal endotoxemia. J Exp Med 1993; 177(4): 1205-8.

[152] Gerard C, Bruyns C, Marchant A, et al. Interleukin 10 reduces the release of tumor necrosis factor and prevents lethality in experimental endotoxemia. J Exp Med 1993; 177(2): 547-50.

[153] Steinhauser ML, Hogaboam CM, Kunkel SL, Lukacs NW, Strieter RM, Standiford TJ. IL-10 is a major mediator of sepsis-induced impairment in lung antibacterial host defense. J Immunol 1999; 162(1): 392-9.

[154] van der Poll T, Marchant A, Keogh CV, Goldman M, Lowry SF. Interleukin-10 impairs host defense in murine pneumococcal pneumonia. J Infect Dis 1996; 174(5): 994-1000.

[155] Eskdale J, Kube D, Tesch H, Gallagher G. Mapping of the human IL10 gene and further characterization of the $5^{\prime}$ flanking sequence. Immunogenetics 1997; 46(2): 120-8.

[156] Lazarus M, Hajeer AH, Turner D, et al. Genetic variation in the interleukin 10 gene promoter and systemic lupus erythematosus. J Rheumatol 1997; 24(12): 2314-7.

[157] Turner DM, Williams DM, Sankaran D, et al. An investigation of polymorphism in the interleukin-10 gene promoter. Eur J Immunogenet $1997 ; 24(1): 1-8$.

[158] Kube D, Platzer C, von Knethen A, et al. Isolation of the human interleukin 10 promoter. Characterization of the promoter activity in Burkitt's lymphoma cell lines. Cytokine 1995; 7(1): 1-7.

[159] Schaaf BM, Boehmke F, Esnaashari H, et al. Pneumococcal septic shock is associated with the interleukin-10-1082 gene promoter polymorphism. Am J Respir Crit Care Med 2003; 168(4): 476-80.

[160] Lowe PR, Galley HF, Abdel-Fattah A, Webster NR. Influence of interleukin-10 polymorphisms on interleukin-10 expression and survival in critically ill patients. Crit Care Med 2003; 31(1): 34-8.

[161] Crawley E, Kay R, Sillibourne J, et al. Polymorphic haplotypes of the interleukin-10 5' flanking region determine variable interleukin10 transcription and are associated with particular phenotypes of juvenile rheumatoid arthritis. Arthritis Rheum 1999; 42(6): 1101-8.

[162] Glynn P, Coakley R, Kilgallen I, Murphy N, O'Neill S. Circulating interleukin 6 and interleukin 10 in community acquired pneumonia. Thorax 1999; 54(1): 51-5.

[163] Gallagher PM, Lowe G, Fitzgerald T, et al. Association of IL-10 polymorphism with severity of illness in community acquired pneumonia. Thorax 2003; 58(2): 154-6.

[164] Reid CL, Perrey C, Pravica V, Hutchinson IV, Campbell IT. Genetic variation in proinflammatory and anti-inflammatory cytokine production in multiple organ dysfunction syndrome. Crit Care Med 2002; 30(10): 2216-21.

[165] van der Pol W, van de Winkel JG. IgG receptor polymorphisms: risk factors for disease. Immunogenetics 1998; 48(3): 222-32.

[166] van Sorge NM, van der Pol WL, van de Winkel JG. FcgammaR polymorphisms: implications for function, disease susceptibility and immunotherapy. Tissue Antigens 2003; 61(3): 189-202.

[167] Koene HR, Kleijer M, Algra J, et al. Fc gammaRIIIa-158V/F polymorphism influences the binding of IgG by natural killer cell
Fc gammaRIIIa, independently of the Fc gammaRIIIa-48L/R/H phenotype. Blood 1997; 90(3): 1109-14.

[168] Breunis WB, van Mirre E, Geissler J, et al. Copy number variation at the FCGR locus includes FCGR3A, FCGR2C and FCGR3B but not FCGR2A and FCGR2B. Hum Mutat 2009; 30(5): E640-50.

[169] Wu J, Edberg JC, Redecha PB, et al. A novel polymorphism of FcgammaRIIIa (CD16) alters receptor function and predisposes to autoimmune disease. J Clin Invest 1997; 100(5): 1059-70.

[170] Huizinga TW, Kleijer M, Tetteroo PA, Roos D, von dem Borne AE. Biallelic neutrophil Na-antigen system is associated with a polymorphism on the phospho-inositol-linked Fc gamma receptor III (CD16). Blood 1990; 75(1): 213-7.

[171] Salmon JE, Edberg JC, Kimberly RP. Fc gamma receptor III on human neutrophils: Allelic variants have functionally distinct capacities. J Clin Invest 1990; 85: 1287-95.

[172] Salmon JE, Millard SS, Brogle NL, Kimberly RP. Fc gamma receptor IIIb enhances Fc gamma receptor IIa function in an oxidant-dependent and allele-sensitive manner. J Clin Invest 1995; 95(6): 2877-85.

[173] Warmerdam PA, van de Winkel JG, Gosselin EJ, Capel PJ. Molecular basis for a polymorphism of human Fc gamma receptor II (CD32). J Exp Med 1990; 172(1): 19-25.

[174] Warmerdam PA, van de Winkel JG, Vlug A, Westerdaal NA, Capel PJ. A single amino acid in the second Ig-like domain of the human Fc gamma receptor II is critical for human IgG2 binding. J Immunol 1991; 147(4): 1338-43.

[175] Parren PW, Warmerdam PA, Boeije LC, et al. On the interaction of IgG subclasses with the low affinity Fc gamma RIIa (CD32) on human monocytes, neutrophils, and platelets. Analysis of a functional polymorphism to human IgG2. J Clin Invest 1992 ; 90(4): 1537-46.

[176] Salmon JE, Edberg JC, Brogle NL, Kimberly RP. Allelic polymorphisms of human Fc gamma receptor IIA and Fc gamma receptor IIIB. Independent mechanisms for differences in human phagocyte function. J Clin Invest 1992; 89(4): 1274-81.

[177] Sanders LA, Feldman RG, Voorhorst-Ogink MM, et al. Human immunoglobulin $\mathrm{G}$ (IgG) Fc receptor IIA (CD32) polymorphism and IgG2-mediated bacterial phagocytosis by neutrophils. Infect Immun 1995; 63(1): 73-81.

[178] Fijen CA, Bredius RG, Kuijper EJ. Polymorphism of IgG Fc receptors in meningococcal disease. Ann Intern Med 1993; 119(7 Pt 1): 636 .

[179] Bredius RG, Derkx BH, Fijen CA, et al. Fc gamma receptor IIa (CD32) polymorphism in fulminant meningococcal septic shock in children. J Infect Dis 1994; 170(4): 848-53.

[180] Platonov AE, Kuijper EJ, Vershinina IV, et al. Meningococcal disease and polymorphism of FcgammaRIIa (CD32) in late complement component-deficient individuals. Clin Exp Immunol 1998; 111(1): 97-101.

[181] Platonov AE, Shipulin GA, Vershinina IV, et al. Association of human Fc gamma RIIa (CD32) polymorphism with susceptibility to and severity of meningococcal disease. Clin Infect Dis 1998; 27(4): 746-50

[182] Fijen CA, Bredius RG, Kuijper EJ, et al. The role of Fcgamma receptor polymorphisms and $\mathrm{C} 3$ in the immune defence against Neisseria meningitidis in complement-deficient individuals. Clin Exp Immunol 2000; 120(2): 338-45.

[183] van der Pol WL, Huizinga TW, Vidarsson G, et al. Relevance of Fcgamma receptor and interleukin-10 polymorphisms for meningococcal disease. J Infect Dis 2001; 184(12): 1548-55.

[184] Domingo P, Muniz-Diaz E, Baraldes MA, et al. Associations between Fc gamma receptor IIA polymorphisms and the risk and prognosis of meningococcal disease. Am J Med 2002; 112(1): 1925.

[185] Yee AM, Phan HM, Zuniga R, Salmon JE, Musher DM. Association between FcgammaRIIa-R131 allotype and bacteremic pneumococcal pneumonia. Clin Infect Dis 2000; 30(1): 25-8.

[186] Lieke A, Sanders M, J.G.J. vdW. Fcgamma receptor IIa (CD32) heterogeneity in patients with recurrent bacterial respiratory tract infections. J Infect Dis 1994; 170: 854-861.

[187] Tezcan I, Berkel AI, Ersoy F, Sanal O, Kanra G. Fc gamma receptor allotypes in children with bacterial meningitis. A preliminary study. Turk J Pediatr 1998; 40(4): 533-8.

[188] Smith I, Vedeler C, Halstensen A. FcgammaRIIa and FcgammaRIIIb polymorphisms were not associated with 
meningococcal disease in Western Norway. Epidemiol Infect 2003; 130(2): 193-9.

[189] Schumann RR, Leong SR, Flaggs GW, et al. Structure and function of lipopolysaccharide binding protein. Science 1990; 249(4975): 1429-31.

[190] Weiss J. Bactericidal/permeability-increasing protein (BPI) and lipopolysaccharide-binding protein (LBP): structure, function and regulation in host defence against Gram-negative bacteria. Biochem Soc Trans 2003; 31(Pt 4): 785-90.

[191] Rintala E, Peuravuori H, Pulkki K, Voipio-Pulkki LM, Nevalainen T. Bactericidal/permeability-increasing protein (BPI) in sepsis correlates with the severity of sepsis and the outcome. Intensive Care Med 2000; 26(9): 1248-51.

[192] Calvano SE, Thompson WA, Marra MN, et al. Changes in polymorphonuclear leukocyte surface and plasma bactericidal/permeability-increasing protein and plasma lipopolysaccharide binding protein during endotoxemia or sepsis. Arch Surg 1994; 129(2): 220-6.

[193] Hubacek JA, Buchler C, Aslanidis C, Schmitz G. The genomic organization of the genes for human lipopolysaccharide binding protein (LBP) and bactericidal permeability increasing protein (BPI) is highly conserved. Biochem Biophys Res Commun 1997; 236(2): 427-30.

[194] Michalek J, Svetlikova P, Fedora M, et al. Bactericidal permeability increasing protein gene variants in children with sepsis. Intensive Care Med 2007; 33(12): 2158-64.

[195] Hubacek JA, Stuber F, Frohlich D, et al. Gene variants of the bactericidal/permeability increasing protein and lipopolysaccharide binding protein in sepsis patients: gender-specific genetic predisposition to sepsis. Crit Care Med 2001; 29(3): 557-61.

[196] Deitch EA, Beck SC, Cruz NC, De Maio A. Induction of heat shock gene expression in colonic epithelial cells after incubation with Escherichia coli or endotoxin. Crit Care Med 1995; 23(8): 1371-6.

[197] Hightower LE. Heat shock, stress proteins, chaperones, and proteotoxicity. Cell 1991; 66(2): 191-7.

[198] Hendrick JP, Hartl FU. Molecular chaperone functions of heatshock proteins. Annu Rev Biochem 1993; 62: 349-84.

[199] Parsell DA, Lindquist S. The function of heat-shock proteins in stress tolerance: degradation and reactivation of damaged proteins. Annu Rev Genet 1993; 27: 437-96.

[200] Hauser GJ, Dayao EK, Wasserloos K, Pitt BR, Wong HR. HSP induction inhibits iNOS mRNA expression and attenuates hypotension in endotoxin-challenged rats. Am J Physiol 1996; 271(6 Pt 2): H2529-35.

[201] Milner CM, Campbell RD. Structure and expression of the three MHC-linked HSP70 genes. Immunogenetics 1990; 32(4): 242-51.

[202] Complete sequence and gene map of a human major histocompatibility complex. The MHC sequencing consortium. Nature 1999; 401(6756): 921-3.

[203] Pociot F, Ronningen KS, Nerup J. Polymorphic analysis of the human MHC-linked heat shock protein 70 (HSP70-2) and HSP70Hom genes in insulin-dependent diabetes mellitus (IDDM). Scand J Immunol 1993; 38(5): 491-5.

[204] Temple SE, Cheong KY, Ardlie KG, Sayer D, Waterer GW. The septic shock associated HSPA1B1267 polymorphism influences production of HSPA1A and HSPA1B. Intensive Care Med 2004; 30(9): 1761-7.

[205] Kee C, Cheong KY, Pham K, Waterer GW, Temple SE. Genetic variation in heat shock protein 70 is associated with septic shock: narrowing the association to a specific haplotype. Int $\mathrm{J}$ Immunogenet 2008; 35(6): 465-73.

[206] Schroeder S, Reck M, Hoeft A, Stuber F. Analysis of two human leukocyte antigen-linked polymorphic heat shock protein 70 genes in patients with severe sepsis. Crit Care Med 1999; 27(7): 1265-70.

[207] Landry DW, Oliver JA. The pathogenesis of vasodilatory shock. N Engl J Med 2001; 345(8): 588-95.

[208] Tran CT, Leiper JM, Vallance P. The DDAH/ADMA/NOS pathway. Atheroscler Suppl 2003; 4(4): 33-40.

[209] Nijveldt RJ, Teerlink T, Van Der Hoven B, et al. Asymmetrical dimethylarginine (ADMA) in critically ill patients: high plasma ADMA concentration is an independent risk factor of ICU mortality. Clin Nutr 2003; 22(1): 23-30.

[210] Siroen MP, van Leeuwen PA, Nijveldt RJ, Teerlink T, Wouters PJ, Van den Berghe G. Modulation of asymmetric dimethylarginine in critically ill patients receiving intensive insulin treatment: a possible explanation of reduced morbidity and mortality? Crit Care Med 2005; 33(3): 504-10.

[211] Jones LC, Tran CT, Leiper JM, Hingorani AD, Vallance P. Common genetic variation in a basal promoter element alters DDAH2 expression in endothelial cells. Biochem Biophys Res Commun 2003; 310(3): 836-43.

[212] O'Dwyer MJ, Dempsey F, Crowley V, et al. Septic shock is correlated with asymmetrical dimethyl arginine levels, which may be influenced by a polymorphism in the dimethylarginine dimethylaminohydrolase II gene: a prospective observational study. Crit Care 2006; 10(5): R139.

[213] Cambien F, Alhenc-Gelas F, Herbeth B, et al. Familial resemblance of plasma angiotensin-converting enzyme level: the Nancy Study. Am J Hum Genet 1988; 43(5): 774-80.

[214] Rigat B, Hubert C, Alhenc-Gelas F, et al. An insertion/deletion polymorphism in the angiotensin I-converting enzyme gene accounting for half the variance of serum enzyme levels. J Clin Invest 1990; 86(4): 1343-6.

[215] Costerousse O, Allegrini J, Lopez M, Alhenc-Gelas F. Angiotensin I-converting enzyme in human circulating mononuclear cells: genetic polymorphism of expression in T-lymphocytes. Biochem $\mathrm{J}$ 1993; 290 (Pt 1): 33-40.

[216] Tiret L, Rigat B, Visvikis S, et al. Evidence, from combined segregation and linkage analysis, that a variant of the angiotensin Iconverting enzyme (ACE) gene controls plasma ACE levels. Am J Hum Genet 1992; 51(1): 197-205.

[217] Rosatto N, Pontremoli R, De Ferrari G, Ravazzolo R. Intron 16 insertion of the angiotensin converting enzyme gene and transcriptional regulation. Nephrol Dial Transplant 1999; 14(4): 868-71.

[218] Spruth E, Zurbrugg HR, Warnecke C, et al. Expression of ACE mRNA in the human atrial myocardium is not dependent on left ventricular function, ACE inhibitor therapy, or the ACE I/D genotype. J Mol Med 1999; 77(11): 804-10.

[219] Suehiro T, Morita T, Inoue M, Kumon Y, Ikeda Y, Hashimoto K. Increased amount of the angiotensin-converting enzyme (ACE) mRNA originating from the ACE allele with deletion. Hum Genet 2004; 115(2): 91-6.

[220] Harding D, Baines PB, Brull D, et al. Severity of meningococcal disease in children and the angiotensin-converting enzyme insertion/deletion polymorphism. Am J Respir Crit Care Med 2002; 165(8): 1103-6.

[221] John Baier R, Loggins J, Yanamandra K. Angiotensin converting enzyme insertion/deletion polymorphism does not alter sepsis outcome in ventilated very low birth weight infants. J Perinatol 2005; 25(3): 205-9.

[222] Villar J, Flores C, Perez-Mendez L, Maca-Meyer N, Espinosa E, Blanco J, et al. Angiotensin-converting enzyme insertion/deletion polymorphism is not associated with susceptibility and outcome in sepsis and acute respiratory distress syndrome. Intensive Care Med 2008; 34(3): 488-95.

[223] Beishuizen A, Thijs LG, Haanen C, Vermes I. Macrophage migration inhibitory factor and hypothalamo-pituitary-adrenal function during critical illness. J Clin Endocrinol Metab 2001; 86(6): 2811-6.

[224] Baugh JA, Bucala R. Macrophage migration inhibitory factor. Crit Care Med 2002; 30(Suppl): S27-S35.

[225] Donnelly SC, Haslett C, Reid PT, et al. Regulatory role for macrophage migration inhibitory factor in acute respiratory distress syndrome. Nat Med 1997; 3(3): 320-3.

[226] Calandra T, Bernhagen J, Mitchell RA, Bucala R. The macrophage is an important and previously unrecognized source of macrophage migration inhibitory factor. J Exp Med 1994; 179(6): 1895-902.

[227] Bozza FA, Gomes RN, Japiassu AM, et al. Macrophage migration inhibitory factor levels correlate with fatal outcome in sepsis. Shock 2004; 22(4): 309-13.

[228] Gao L, Flores C, Fan-Ma S, et al. Macrophage migration inhibitory factor in acute lung injury: expression, biomarker, and associations. Transl Res 2007; 150(1): 18-29.

[229] Goring K, Huang Y, Mowat C, et al. Mechanisms of human complement factor $\mathrm{B}$ induction in sepsis and inhibition by activated protein C. Am J Physiol Cell Physiol 2009; 296(5): C1140-50.

[230] Pravica V, Asderakis A, Perrey C, et al. In vitro production of IFNgamma correlates with $\mathrm{CA}$ repeat polymorphism in the human IFN-gamma gene. Eur J Immunogenet 1999; 26(1): 1-3. 
[231] Pravica V, Perrey C, Stevens A, Lee JH, Hutchinson IV. A single nucleotide polymorphism in the first intron of the human IFNgamma gene: absolute correlation with a polymorphic CA microsatellite marker of high IFN-gamma production. Hum Immunol 2000; 61(9): 863-6.

[232] Stassen NA, Leslie-Norfleet LA, Robertson AM, Eichenberger MR, Polk HC, Jr. Interferon-gamma gene polymorphisms and the development of sepsis in patients with trauma. Surgery 2002; 132(2): 289-92.

[233] Ross OA, McCormack R, Maxwell LD, et al. mt4216C variant in linkage with the mtDNA TJ cluster may confer a susceptibility to mitochondrial dysfunction resulting in an increased risk of Parkinson's disease in the Irish. Exp Gerontol 2003; 38(4): 397405.

[234] Gomez R, O'Keeffe T, Chang LY, et al. Association of mitochondrial allele $4216 \mathrm{C}$ with increased risk for complicated sepsis and death after traumatic injury. J Trauma 2009; 66(3): 8507; discussion 857-8.

[235] Huebinger RM, Gomez R, McGee D, et al. Association of Mitochondrial Allele 4216C with Increased Risk for Sepsis-Related Organ Dysfunction and Shock after Burn Injury. Shock 2010; 33(1): 19-23.

[236] Aird WC. Vascular bed-specific hemostasis: role of endothelium in sepsis pathogenesis. Crit Care Med 2001; 29(7 Suppl): S28-34; discussion S34-5.

[237] Paramo JA, Perez JL, Serrano M, Rocha E. Types 1 and 2 plasminogen activator inhibitor and tumor necrosis factor alpha in patients with sepsis. Thromb Haemost 1990; 64(1): 3-6.

[238] Brandtzaeg P, Joo GB, Brusletto B, Kierulf P. Plasminogen activator inhibitor 1 and 2, alpha-2-antiplasmin, plasminogen, and endotoxin levels in systemic meningococcal disease. Thromb Res 1990; 57(2): 271-8.

[239] Suffredini AF, Harpel PC, Parrillo JE. Promotion and subsequent inhibition of plasminogen activation after administration of intravenous endotoxin to normal subjects. N Engl J Med 1989; 320(18): 1165-72.

[240] Faust SN, Heyderman RS, Levin M. Coagulation in severe sepsis: a central role for thrombomodulin and activated protein C. Crit Care Med 2001; 29(Suppl 7): S62-7; discussion S67-8.

[241] Faust SN, Levin M, Harrison OB, et al. Dysfunction of endothelial protein $\mathrm{C}$ activation in severe meningococcal sepsis. N Engl $\mathrm{J}$ Med 2001; 345(6): 408-16.

[242] Coughlin SR. Thrombin signalling and protease-activated receptors. Nature 2000; 407(6801): 258-64.

[243] Vergnolle N, Cellars L, Mencarelli A, et al. A role for proteinaseactivated receptor-1 in inflammatory bowel diseases. J Clin Invest 2006; $116(7): 2056$.

[244] Cirino G, Vergnolle N. Proteinase-activated receptors (PARs): crossroads between innate immunity and coagulation. Curr Opin Pharmacol 2006; 6(4): 428-34.

[245] Kambas K, Markiewski MM, Pneumatikos IA, et al. C5a and TNFalpha up-regulate the expression of tissue factor in intra-alveolar neutrophils of patients with the acute respiratory distress syndrome. J Immunol 2008; 180(11): 7368-75.

[246] Pawlinski R, Pedersen B, Schabbauer G, et al. Role of tissue factor and protease-activated receptors in a mouse model of endotoxemia. Blood 2004; 103(4): 1342-7.

[247] Weiler H, Lindner V, Kerlin B, et al. Characterization of a mouse model for thrombomodulin deficiency. Arterioscler Thromb Vasc Biol 2001; 21(9): 1531-7.

[248] Sapru A, Wiemels JL, Witte JS, Ware LB, Matthay MA. Acute lung injury and the coagulation pathway: Potential role of gene polymorphisms in the protein $\mathrm{C}$ and fibrinolytic pathways. Intensive Care Med 2006; 32(9): 1293-303.

[249] Leclerc F, Hazelzet J, Jude B, et al. Protein C and S deficiency in severe infectious purpura of children: a collaborative study of 40 cases. Intensive Care Med 1992; 18(4): 202-5.

[250] Fourrier F, Lestavel P, Chopin C, et al. Meningococcemia and purpura fulminans in adults: acute deficiencies of proteins $\mathrm{C}$ and $\mathrm{S}$ and early treatment with antithrombin III concentrates. Intensive Care Med 1990; 16(2): 121-4.

[251] Bernard GR, Vincent JL, Laterre PF, et al. Efficacy and safety of recombinant human activated protein $\mathrm{C}$ for severe sepsis. $\mathrm{N}$ Engl J Med 2001; 344(10): 699-709.

[252] Spek CA, Koster T, Rosendaal FR, Bertina RM, Reitsma PH. Genotypic variation in the promoter region of the protein $\mathrm{C}$ gene is associated with plasma protein $\mathrm{C}$ levels and thrombotic risk. Arterioscler Thromb Vasc Biol 1995; 15(2): 214-8.

[253] Scopes D, Berg LP, Krawczak M, Kakkar VV, Cooper DN Polymorphic variation in the human protein $\mathrm{C}$ (PROC) gene promoter can influence transcriptional efficiency in vitro. Blood Coagul Fibrinolysis 1995; 6(4): 317-21.

[254] Aiach M, Nicaud V, Alhenc-Gelas M, et al. Complex association of protein $\mathrm{C}$ gene promoter polymorphism with circulating protein $\mathrm{C}$ levels and thrombotic risk. Arterioscler Thromb Vasc Biol 1999; 19(6): 1573-6.

[255] Binder A, Endler G, Rieger S, et al. Protein C promoter polymorphisms associate with sepsis in children with systemic meningococcemia. Hum Genet 2007; 122(2): 183-90.

[256] Chen QX, Wu SJ, Wang HH, et al. Protein C -1641A/-1654C haplotype is associated with organ dysfunction and the fatal outcome of severe sepsis in Chinese Han population. Hum Genet 2008; 123(3): 281-7.

[257] Walley KR, Russell JA. Protein C -1641 AA is associated with decreased survival and more organ dysfunction in severe sepsis. Crit Care Med 2007; 35(1): 12-7.

[258] Russell JA, Wellman H, Walley KR. Protein C rs2069912 C allele is associated with increased mortality from severe sepsis in North Americans of East Asian ancestry. Hum Genet 2008; 123(6): 6613 .

[259] Skogen WF, Senior RM, Griffin GL, Wilner GD. Fibrinogenderived peptide B beta $1-42$ is a multidomained neutrophil chemoattractant. Blood 1988; 71(5): 1475-9.

[260] Leavell KJ, Peterson MW, Gross TJ. The role of fibrin degradation products in neutrophil recruitment to the lung. Am J Respir Cell Mol Biol 1996; 14(1): 53-60.

[261] Kuhns DB, Nelson EL, Alvord WG, Gallin JI. Fibrinogen induces IL-8 synthesis in human neutrophils stimulated with formylmethionyl-leucyl-phenylalanine or leukotriene B(4). J Immunol 2001; 167(5): 2869-78.

[262] Tsakadze NL, Zhao Z, D'Souza SE. Interactions of intercellular adhesion molecule-1 with fibrinogen. Trends Cardiovasc Med 2002; 12(3): 101-8.

[263] Forsyth CB, Solovjov DA, Ugarova TP, Plow EF. Integrin alpha(M)beta(2)-mediated cell migration to fibrinogen and its recognition peptides. J Exp Med 2001; 193(10): 1123-33.

[264] Maghzal GJ, Brennan SO, George PM. Fibrinogen B beta polymorphisms do not directly contribute to an altered in vitro clot structure in humans. Thromb Haemost 2003; 90(6): 1021-8.

[265] Manocha S, Russell JA, Sutherland AM, Wattanathum A, Walley KR. Fibrinogen-beta gene haplotype is associated with mortality in sepsis. J Infect 2007; 54(6): 572-7.

[266] Hartel C, Konig I, Koster S, et al. Genetic polymorphisms of hemostasis genes and primary outcome of very low birth weight infants. Pediatrics 2006; 118(2): 683-9.

[267] Dawson SJ, Wiman B, Hamsten A, et al. The two allele sequences of a common polymorphism in the promoter of the plasminogen activator inhibitor-1 (PAI-1) gene respond differently to interleukin-1 in HepG2 cells. J Biol Chem 1993; 268(15): 1073945.

[268] Eriksson P, Kallin B, van 't Hooft FM, Bavenholm P, Hamsten A. Allele-specific increase in basal transcription of the plasminogenactivator inhibitor 1 gene is associated with myocardial infarction. Proc Natl Acad Sci U S A 1995; 92(6): 1851-5.

[269] Hermans PW, Hibberd ML, Booy R, et al. 4G/5G promoter polymorphism in the plasminogen-activator-inhibitor-1 gene and outcome of meningococcal disease. Meningococcal Research Group. Lancet 1999; 354(9178): 556-60.

[270] Haralambous E, Hibberd ML, Hermans PW, et al. Role of functional plasminogen-activator-inhibitor-1 4G/5G promoter polymorphism in susceptibility, severity, and outcome of meningococcal disease in Caucasian children. Crit Care Med 2003; 31(12): 2788-93.

[271] Geishofer G, Binder A, Muller M, et al. 4G/5G promoter polymorphism in the plasminogen-activator-inhibitor-1 gene in children with systemic meningococcaemia. Eur J Pediatr 2005; 164(8): 486-90.

[272] Garcia-Segarra G, Espinosa G, Tassies D, et al. Increased mortality in septic shock with the $4 \mathrm{G} / 4 \mathrm{G}$ genotype of plasminogen activator inhibitor 1 in patients of white descent. Intensive Care Med 2007; 33(8): 1354-62. 
[273] Peres Wingeyer S, de Larranaga G, Cunto E, et al. Role of 4G/5G promoter polymorphism of Plasminogen Activator Inhibitor-1 (PAI-1) gene in outcome of sepsis. Thromb Res 2010; 125: 367-9.

[274] Sapru A, Hansen H, Ajayi T, et al. 4G/5G polymorphism of plasminogen activator inhibitor-1 gene is associated with mortality in intensive care unit patients with severe pneumonia. Anesthesiology 2009; 110(5): 1086-91.

[275] Westendorp RG, Hottenga JJ, Slagboom PE. Variation in plasminogen-activator-inhibitor-1 gene and risk of meningococcal septic shock. Lancet 1999; 354(9178): 561-3.

[276] Lazarus R, Vercelli D, Palmer LJ, et al. Single nucleotide polymorphisms in innate immunity genes: abundant variation and potential role in complex human disease. Immunol Rev 2002; 190: 9-25.

[277] Clark MF, Baudouin SV. A systematic review of the quality of genetic association studies in human sepsis. Intensive Care Med 2006; 32(11): 1706-12.

[278] Summerfield JA, Ryder S, Sumiya M, et al. Mannose binding protein gene mutations associated with unusual and severe infections in adults. Lancet 1995; 345(8954): 886-9.

[279] Majetschak M, Flohe S, Obertacke U, et al. Relation of a TNF gene polymorphism to severe sepsis in trauma patients. Ann Surg 1999; 230(2): 207-14.

[280] Pappachan JV, Coulson TG, Child NJ, et al. Mortality in adult intensive care patients with severe systemic inflammatory response syndromes is strongly associated with the hypo-immune TNF 238A polymorphism. Immunogenetics 2009; 61(10): 657-62.

[281] Michalek J, Svetlikova P, Fedora M, et al. Interleukin-6 gene variants and the risk of sepsis development in children. Hum Immunol 2007; 68(9): 756-60.

[282] Wattanathum A, Manocha S, Groshaus H, Russell JA, Walley KR. Interleukin-10 haplotype associated with increased mortality in critically ill patients with sepsis from pneumonia but not in patients with extrapulmonary sepsis. Chest 2005; 128(3): 1690-8.

[283] Schroder O, Schulte KM, Ostermann P, et al. Heat shock protein 70 genotypes HSPA1B and HSPA1L influence cytokine concentrations and interfere with outcome after major injury. Crit Care Med 2003; 31(1): 73-9.

[284] Flores C, Maca-Meyer N, Perez-Mendez L, et al. A CXCL2 tandem repeat promoter polymorphism is associated with susceptibility to severe sepsis in the Spanish population. Genes Immun 2006; 7(2): 141-9.

[285] Villar J, Perez-Mendez L, Flores C, et al. A CXCL2 polymorphism is associated with better outcomes in patients with severe sepsis*. Crit Care Med 2007; 35(10): 2292-7.

[286] Eklund C, Huttunen R, Syrjanen J, et al. Polymorphism of the Creactive protein gene is associated with mortality in bacteraemia. Scand J Infect Dis 2006; 38(11-12): 1069-73.

[287] Roy S, Hill AV, Knox K, Griffiths D, Crook D. Research pointers: Association of common genetic variant with susceptibility to invasive pneumococcal disease. BMJ 2002; 324(7350): 1369. 